\title{
Vaccine Considerations for Multiple Sclerosis in the COVID-19 Era
}

\author{
Patricia K. Coyle · Anne Gocke · Megan Vignos (D) · Scott D. Newsome
}

Received: March 23, 2021 / Accepted: April 24, 2021 / Published online: June 1, 2021

(C) The Author(s) 2021

\begin{abstract}
People with multiple sclerosis (MS) are at risk for infections that can result in amplification of baseline symptoms and possibly trigger clinical relapses. Vaccination can prevent infection through the activation of humoral and cellular immune responses. This is particularly pertinent in the era of emerging novel vaccines against severe acute respiratory syndrome coronavirus 2 , the virus that causes coronavirus disease 2019 (COVID-19). MS disease-modifying therapies (DMTs), which affect the immune system, may impact immune responses to COVID-19 vaccines in people with MS. The objective of this article is to provide information on immune system responses to vaccinations and review previous studies of vaccine responses in people with MS to support the
\end{abstract}

P. K. Coyle

Department of Neurology, Stony Brook University

Medical Center, Stony Brook, NY, USA

A. Gocke · M. Vignos

Biogen, Cambridge, MA, USA

S. D. Newsome

Johns Hopkins University School of Medicine,

Baltimore, MD, USA

M. Vignos ( $\square)$

US Medical MS Franchise and Interferons, Biogen,

133 Boston Post Rd, Weston, MA 20493, USA

e-mail: megan.vignos@biogen.com safety and importance of receiving currently available and emerging COVID-19 vaccines. Immunological studies have shown that coordinated interactions between $\mathrm{T}$ and B lymphocytes of the adaptive immune system are key to successful generation of immunological memory and production of neutralizing antibodies following recognition of vaccine antigens by innate immune cells. $\mathrm{CD} 4^{+} \mathrm{T}$ cells are essential to facilitate $\mathrm{CD}^{+} \mathrm{T}$ cell and $\mathrm{B}$ cell activation, while B cells drive and sustain T cell memory. Data suggest that some classes of DMT, including type 1 interferons and glatiramer acetate, may not significantly impair the response to vaccination. DMTs-such as sphingosine-1phosphate receptor modulators, which sequester lymphocytes from circulation; alemtuzumab; and anti-CD20 therapies, which rely on depleting populations of immune cellshave been shown to attenuate responses to conventional vaccines. Currently, three COVID-19 vaccines have been granted emergency use authorization in the USA on the basis of promising interim findings of ongoing trials. Because analyses of these vaccines in people with MS are not available, decisions regarding COVID-19 vaccination and DMT choice should be informed by data and expert consensus, and personalized with considerations for disease burden, risk of infection, and other factors. 
Keywords: COVID-19; Multiple sclerosis; SARSCoV-2; Vaccines

\section{Key Summary Points}

People with multiple sclerosis (MS) may be at increased risk for infection, which can lead to relapses or pseudo-relapses.

Vaccines are an important health measure to prevent infections and require activation of humoral and cellular immune responses.

Some disease-modifying therapies (DMTs) for MS-including sphingosine-1phosphate receptor modulators, which sequester lymphocytes from circulation; alemtuzumab (anti-CD52); anti-CD20 therapies; and cladribine (impairs DNA synthesis)—exert effects on humoral and cellular immune activity that may affect the response to available and emerging coronavirus disease 2019 (COVID-19) vaccines.

Coordinated interactions between $\mathrm{T}$ and B lymphocytes of the adaptive immune system are integral to the successful generation of immunological memory and the production of neutralizing antibodies.

Risks versus benefits of timing vaccinations to ensure maximum vaccine efficacy, as outlined in vaccination guidance and guidelines developed by national and international MS groups, should be considered in the decision to receive a COVID-19 vaccine-even if efficacy may be compromised-when disease burden is high.

\section{DIGITAL FEATURES}

This article is published with digital features, including an educational video, to facilitate understanding of the article. To view digital features for this article go to https://doi.org/10. 6084/m9.figshare.14459775.

\section{INTRODUCTION}

Multiple sclerosis (MS) is an inflammatory, demyelinating, neurodegenerative disease of the central nervous system that causes significant and irreversible neurological disability $[1,2]$. An estimated 2.8 million people are living with MS worldwide, including almost 1 million people in the USA; global prevalence in 2020 was 35.9 per 100,000 persons and is expected to rise $[3,4]$. Although the etiology of MS is unknown, a number of environmental, genetic, and epigenetic factors are believed to contribute to immunopathogenesis of MS [5].

People with MS are at increased risk for acquiring certain types of infections, including respiratory and other viral and bacterial infections [6-8]. Additionally, certain disease-modifying therapies (DMTs), which suppress or alter the immune system, have been associated with increased risk of upper respiratory tract infections, urinary tract infections, and other infections [9]. This is relevant for people with MS because bacterial and viral infections have been shown to be associated with new or worsening baseline MS symptoms in the form of relapses or pseudo-relapses [10]. Upper respiratory tract infections can double the risk for relapse [11]. Furthermore, increased rates of influenza in the general population are temporally associated with a greater occurrence of relapses in people with MS [12]. It is speculated that relapses associated with an infection can be more neurologically damaging than those unrelated to infection [13]. Therefore, measures to prevent infection are particularly important for people with MS.

Over the years, there have been numerous iterations of consensus statements regarding the risks and benefits of vaccination in people with MS [14-20]. National and international guidance and guidelines generally agree that the benefits of vaccination outweigh any potential risks. The only exception is with live attenuated vaccines, which should not be used in people 
who are currently receiving or have recently discontinued immunosuppressive or immunomodulating DMTs, unless the risk of infection is elevated and nonlive vaccines are not available. The reason for this is that a live virus or bacteria has the potential to cause an infection and if the vaccine is administered during treatment with a MS DMT, the ability of the immune response to clear the infection could be impaired, which could possibly result in worsening of MS symptoms. Some DMTs exert effects on humoral and cellular immune activity that may affect the response to vaccination [21, 22].

Data on the efficacy of vaccinations in people with MS receiving immunosuppressive or immunomodulatory DMTs are still lacking, leading to a great deal of variability at the local, national, and international level with regard to vaccine guidance and guidelines [15-17, 19]. A better understanding of how DMTs for MS may influence vaccine safety and efficacy has become even more urgent given the current coronavirus disease 2019 (COVID-19) pandemic and recent authorization of vaccines specific for the novel severe acute respiratory syndrome coronavirus 2 (SARS-CoV-2), the virus responsible for COVID-19.

The incidence of COVID-19 in people with MS ranges from below $1 \%$ to $11 \%$ (including suspected but not confirmed cases) in studies that included a cross-sectional mixed method study, retrospective cohort analysis, and a prospective observational cohort study compared with World Health Organization (WHO) estimates of 1432 per 100,000 globally, and 8424 per 100,000 in the USA in the general population [23-26]. COVID-19-related MS mortality has been reported to be approximately $1-4 \%$ overall (compared with a casefatality ratio in the general population of $0.0-9.2 \%$ in the 20 countries most affected by COVID-19, including the USA, which has a rate of $1.8 \%$ [according to Johns Hopkins University]), and more than $50 \%$ of deaths have occurred in people not receiving MS DMTs [27-29]. An analysis of data in people with MS from 28 countries who had suspected or con- firmed COVID-19 found that treatment with ocrelizumab or rituximab was associated with significantly increased risk of hospitalization and admission to the intensive care unit compared with other pooled DMTs (including alemtuzumab, cladribine, dimethyl fumarate, fingolimod, glatiramer acetate, interferon, natalizumab, and teriflunomide) [30]. Rituximab was also associated with significantly increased risk of artificial ventilation [30]. In a recent retrospective study from electronic health records, interferons and glatiramer acetate were shown to be associated with reduced COVID-19 risk, whereas anti-CD20 therapies were associated with increased risk, within the treated MS cohort [31]. In contrast, an analysis of COViMS registry data from 1626 patients with MS found that poorer clinical COVID-19 outcomes (including mortality) were associated with older patient age and greater disability whereas use of rituximab was associated with increased risk of hospitalization [32]. These findings suggest that the use of these anti-CD20 agents could be a risk factor for more severe infection.

Up to $98 \%$ of neurologists surveyed were concerned about their patients with MS contracting COVID-19, and 80\% thought that certain DMTs would not permit a protective response to a COVID-19 vaccine [33]. Clinicians were most concerned about vaccine response and concomitant treatment with ocrelizumab $(84 \%)$, rituximab $(83 \%)$, and alemtuzumab (78\%) [33], suggesting that prolonged $\mathrm{T}$ and $\mathrm{B}$ cell depletion is an important consideration. However, there may be an optimal timing of vaccination with some DMTs in order to achieve the best vaccine immune response.

This review will discuss the immune system, immunological effects of vaccination, existing data on the effects of DMTs on vaccination efficacy, and vaccine considerations in people with MS as they relate to currently available and emerging COVID-19 vaccines. This article is based on previously conducted studies and does not contain any new studies with human participants or animals performed by any of the authors. 
Table 1 Types of vaccines

\begin{tabular}{|c|c|c|}
\hline Vaccine type & MOA/effect & Examples \\
\hline \multicolumn{3}{|l|}{ Major types [47] } \\
\hline $\begin{array}{l}\text { Live attenuated } \\
{[40,48]}\end{array}$ & $\begin{array}{l}\text { Weakened version of the pathogen } \\
\text { Cause } \mathrm{CD}^{+} \text {cytotoxic } \mathrm{T} \text { cell generation and } \\
\text { recruitment of antigen-specific } \mathrm{CD} 4^{+} \mathrm{T} \text { helper } \\
\text { cells (i.e., a T-dependent antibody response) } \\
\text { Confer immunity that lasts for decades } \\
\text { Generally contraindicated in those with } \\
\text { weakened immune systems }\end{array}$ & $\begin{array}{l}\text { Smallpox } \\
\text { Yellow fever } \\
\text { Measles } \\
\text { Chicken pox } \\
\text { Oral polio vaccine }\end{array}$ \\
\hline $\begin{array}{l}\text { Inactivated whole } \\
\text { cell }[36,48,49]\end{array}$ & $\begin{array}{l}\text { More stable and safer than live vaccines, as dead } \\
\text { microbe cannot mutate back to its virulent } \\
\text { form } \\
\text { Often poorly immunogenic and require additives } \\
\text { or adjuvants, such as aluminum salts, oil-in- } \\
\text { water emulsions, and saponins to help } \\
\text { stimulate antibody and effector T cell immune } \\
\text { functions } \\
\text { Protection may be of shorter duration; booster } \\
\text { vaccinations may be required }\end{array}$ & $\begin{array}{l}\text { Inactivated polio } \\
\text { Whole cell polio }\end{array}$ \\
\hline $\begin{array}{l}\text { Subunit (purified } \\
\text { antigen) } \\
{[40,47-51]}\end{array}$ & $\begin{array}{l}\text { Include protein-based, polysaccharide, and } \\
\text { conjugate types } \\
\text { Often poorly immunogenic and require additives } \\
\text { or adjuvants, such as aluminum salts, oil-in- } \\
\text { water emulsions, and saponins to help } \\
\text { stimulate antibody and effector T cell immune } \\
\text { functions } \\
\text { Can contain up to } 20 \text { antigenic determinants, } \\
\text { i.e., epitopes of the antigen that are recognized } \\
\text { by antibodies and } T \text { cells } \\
\text { Reversion to a virulent form cannot occur } \\
\text { Determination of antigen combinations must be } \\
\text { made to elicit effective immune response }\end{array}$ & $\begin{array}{l}\text { Acellular pertussis }(\mathrm{aP}) \\
\text { Haemophilus influenzae type b (Hib) } \\
\text { Pneumococcal (PCV-7, PCV-10, PCV-13) } \\
\text { Hepatitis B (HepB) } \\
\text { COVID-19 }\end{array}$ \\
\hline
\end{tabular}


Table 1 continued

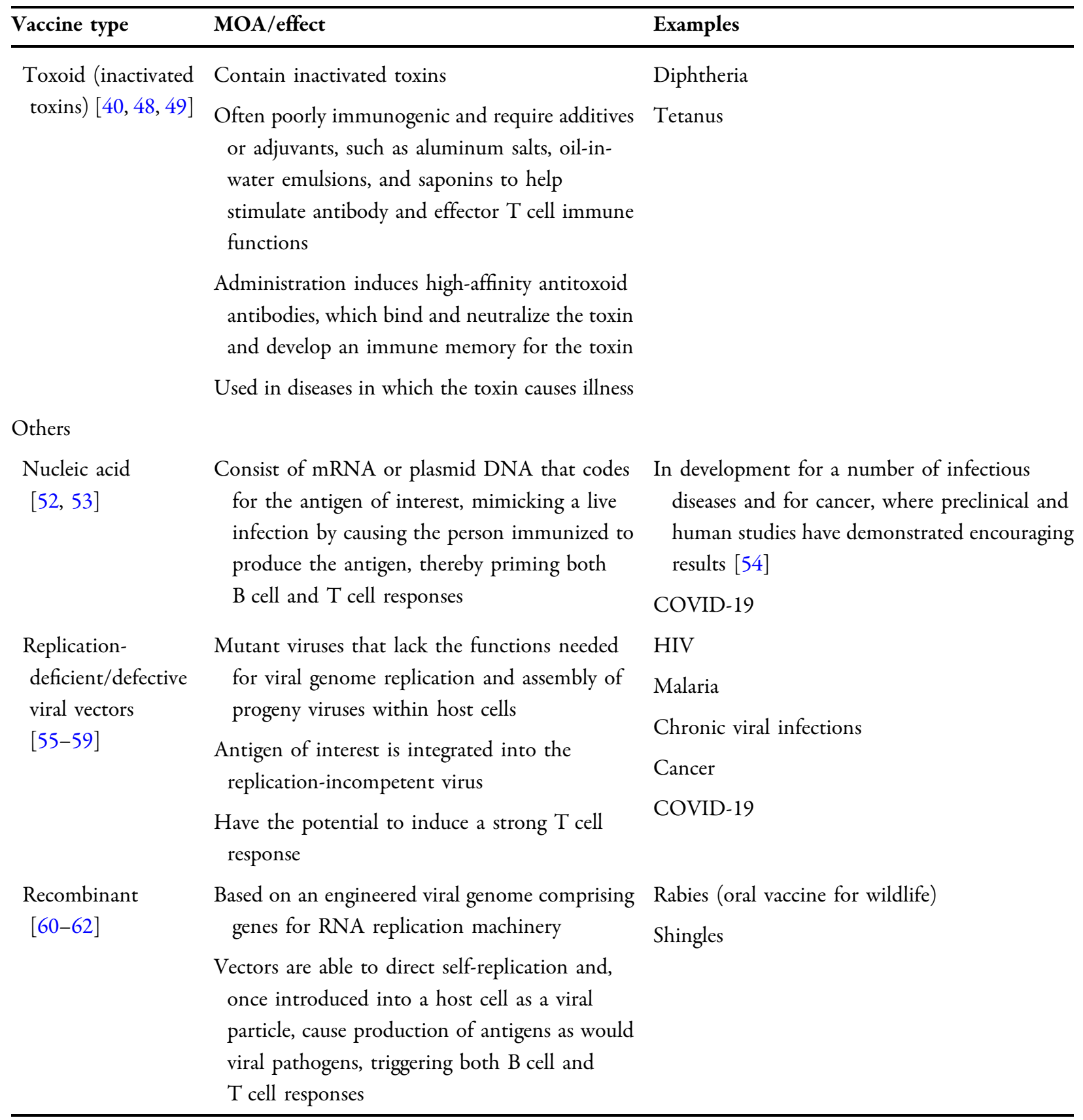

$M O A$ mechanism of action, $m R N A$ messenger RNA

\section{THE IMMUNE SYSTEM}

The immune system is composed of two arms: the innate system and the adaptive or acquired system. It is the complex interplay between these two arms that comprises the normal immunological response to foreign antigens. The innate immune system is the first line of defense against infection; it plays a crucial role 
a

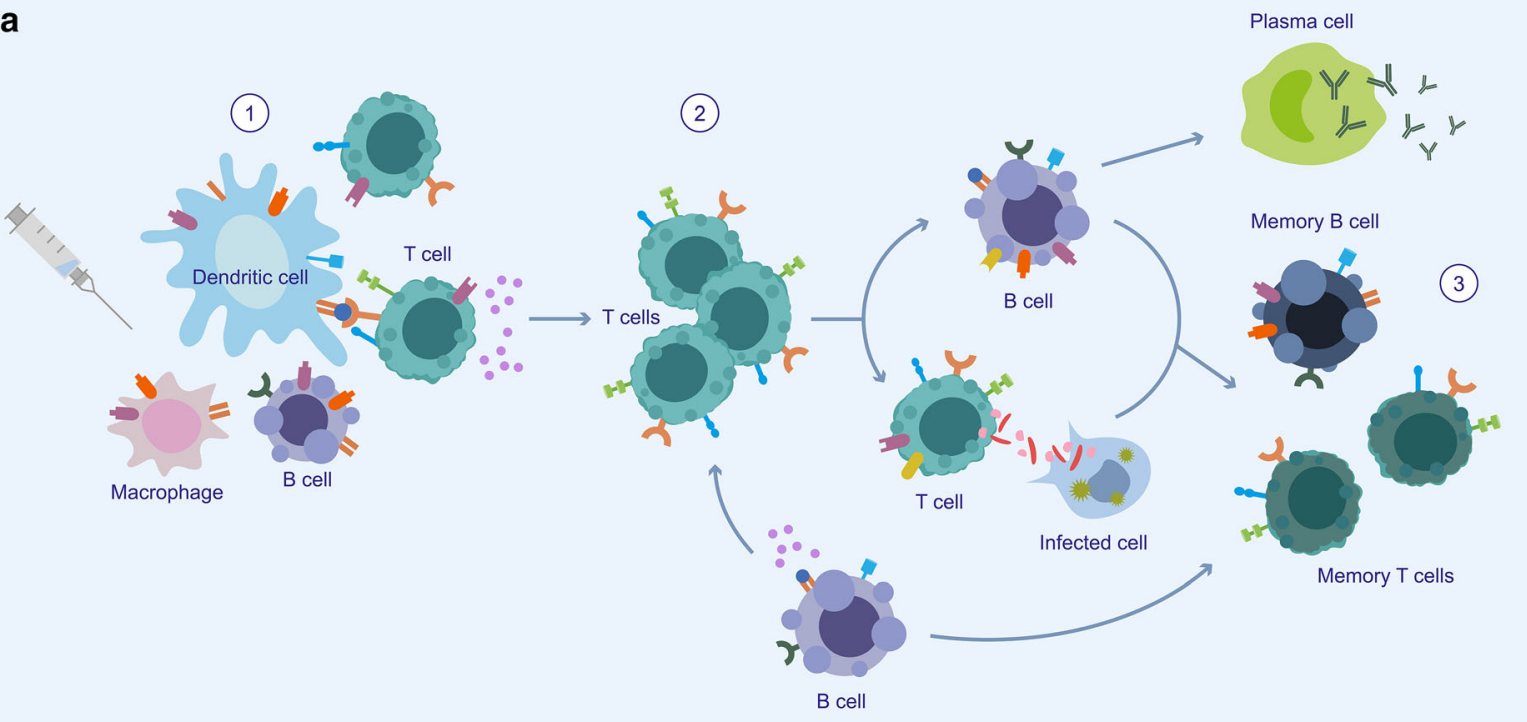

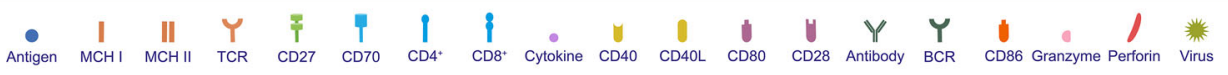

b

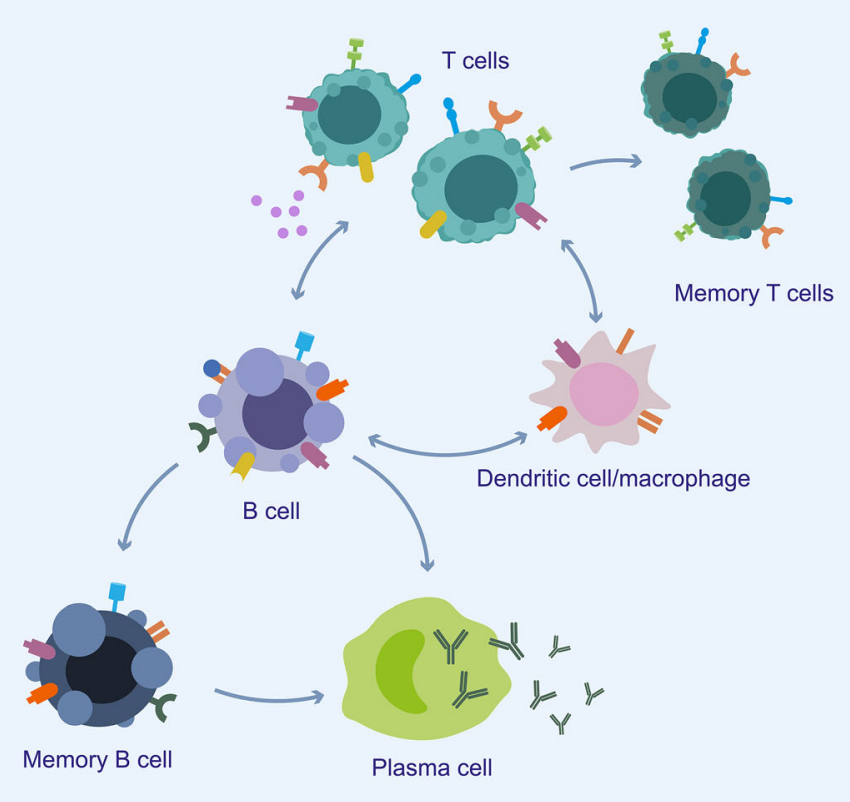

- | || \begin{tabular}{l}
|| \\
\hline
\end{tabular}

Antigen MCHI MCH II TCR CD27 CD70 CD4+ CD8 $^{+}$Cytokine CD40 CD40L CD80 CD28 Antibody BCR CD86 
4 Fig. 1 Immune response to vaccination. a Occurs in multiple steps: (1) An APC (e.g., dendritic cells, macrophage, or $\mathrm{B}$ cell) recognizes vaccine antigen, resulting in local inflammation; and internalizes, processes, and presents antigen to $\mathrm{CD}^{+} \mathrm{T}$ cell in MHC class II. (2) Antigen-specific $T$ cell becomes activated, differentiates, and secretes cytokines to support B cell activation. $\mathrm{B}$ cells become activated via interaction with $\mathrm{T}$ cells (contact-dependent or contact-independent [involving cytokines]) and differentiate into plasma cell/plasma blast, which produces neutralizing antibodies that can prevent future infection. $\mathrm{T}\left(\mathrm{CD}^{+}\right.$and $\left.\mathrm{CD}^{+}\right)$and $\mathrm{B}$ cells proliferate, but dendritic cells become limited to support continued differentiation. B cells take over to help continued differentiation and proliferation of $\mathrm{T}$ cells by providing late co-stimulatory signals and secretion of cytokines/survival signals that enhance $T$ cell memory formation. (3) Optimal immune memory results (i.e., more memory $\mathrm{CD}^{+} \mathrm{T}$ cells, better survival, and enhanced cytotoxicity). Approximately $10 \%$ of activated B and $\mathrm{T}$ cells become memory cells to help prevent disease in the future. Without B cells, suboptimal memory results (fewer cells, poor survival, and decreased cytotoxicity in cells that remain). $\mathbf{b} \mathrm{B}$ and $\mathrm{T}$ cell interactions are bidirectional and form an integral part of the immune response to vaccination. APC antigen-presenting cell, MHC major histocompatibility complex

in the initial recognition of pathogens and in the activation of the cells of the adaptive immune system. Cells that are involved in innate immune responses include monocytes/macrophages, dendritic cells, mast cells, neutrophils, eosinophils, natural killer cells, and natural killer T cells [34]. These cells express receptors such as pattern recognition receptors, which are not specific to any particular pathogen and allow the cells to react to microbes containing common molecular structures, and pathogen-associated molecular patterns, including liposaccharides, other bacterial cell wall components, and virus-derived doublestranded RNA [35]. Innate immune responses occur more rapidly than adaptive immune responses and are generated within minutes to hours of infection [36]. However, subsequent encounters with the same pathogen will not elicit a faster or stronger response (i.e., no innate immunological memory is created) [36].

\section{The Adaptive Immune System}

The adaptive immune system is activated 4-7 days after exposure to a pathogen [37] in response to interactions between antigens, antigen receptor-bearing lymphocytes (T cells), and antigen-presenting cells (APCs); the lattermost can be specific cells of the innate immune system or B cells (Fig. 1) [37, 38]. The coordinated interactions between $\mathrm{T}$ and $\mathrm{B}$ lymphocytes of the adaptive immune system are integral to the immune system's response when called into action by the innate immune cells [39]. Both T and B cells express unique antigenbinding receptors on their cell membranes [35]. Each cell expresses a single type of receptor and has the ability to rapidly proliferate and differentiate when activated.

\section{Cellular Response}

T cells mediate the cellular immune response [40-42]. They are activated by APCs that have digested an antigen and are displaying a peptide from the antigen on their membrane (bound by major histocompatibility complex molecules) [35]. Specific subtypes of T cell are produced and have differentiated functions, including $\mathrm{CD}^{+}$ (cytotoxic T cells), $\mathrm{CD}^{+}$(helper T cells), and follicular $\mathrm{T}$ helper cells, among others [40]. $\mathrm{CD}^{+} \mathrm{T}$ cells reduce, control, and eliminate intracellular pathogens by directly (via release of perforin, granzyme, etc.) or indirectly (via antimicrobial cytokine release) killing infected cells [40]. $\mathrm{CD}^{+} \mathrm{T}$ cells are involved in the reduction, control, and clearance of extracellular and intracellular pathogens. This occurs through the release of cytokines that support the activation and differentiation of B cells, $\mathrm{CD}^{+} \mathrm{T}$ cells, and macrophages, contributing to defense against bacteria and viruses on mucosal surfaces [40]. Subsets of $\mathrm{CD}^{+}{ }^{+} \mathrm{T}$ cells include $\mathrm{T}$ helper 1, 2, 9, and 17 cells; regulatory T cells; and, as mentioned previously, follicular $\mathrm{T}$ helper cells [43], which provide an intricate and highly specific response to the pathogen. 


\section{Humoral Response}

The cellular immunity that is achieved by the differentiation and production of antigenspecific T cell populations is important, but it is only one part of the adaptive immune response. The other part is humoral immunity, which is composed of B cells, the complement system, and antibodies [38, 40,44].

$B$ cells are activated by cytokines released by T helper cells (e.g., interleukin [IL]-4, IL-5, IL-5, IL-13) and upon activation differentiate into plasma cells, which produce antibodies $[37,40,45]$. B cells can also recognize antigens directly, without the involvement of APCs of the innate immune system [35]. Antibodies stop or reduce infections via clearance of extracellular pathogens through binding to the enzymatic active sites of toxins or preventing their diffusion, by neutralizing viral cell entry, promoting phagocytosis of extracellular bacteria, and activating the complement cascade [40]. Additionally, B cells play a role in the further activation of $\mathrm{T}$ cells and are involved in both antigen presentation to $T$ cells and the generation of immunological memory [46]. Immunological memory is the capability of the immune system to respond more quickly and effectively to pathogens encountered earlier, and is based on persistent populations of clonally expanded, specialized memory $\mathrm{T}$ and B cells [37]. Complement factors opsonize antigens, which can then stimulate the complement receptor 2 expressed on B cells and lower the threshold for producing neutralizing antibodies [44].

\section{Vaccine-Related Immune Response}

Vaccines exert their effects through the immune system and rely on both the innate and adaptive arms interacting in a complex and complementary fashion with the goal of generating immunological memory [35]. A variety of vaccine types exist, as shown in Table 1, and they elicit varying degrees of long-term immunological response.

In response to vaccination, the innate, humoral (B cell mediated), and cellular ( $T$ cell mediated) immune pathways are activated through multiple steps (Fig. 1) [42, 45]. Initially, inflammation occurs at the site of administration, which can be intramuscular, subcutaneous, oral, or pulmonary/nasal, and is followed by activation of the innate system $[45,63]$. The site of administration can affect the immune response [64]. For example, immunization via parenteral administration can fail to induce mucosal immunity [63], while pulmonary/nasal administration of experimental nanoparticle vaccination has resulted in high-frequency, long-lasting, antigen-specific effector memory $\mathrm{T}$ cell response at mucosal sites and increased antigen transport [65].

Following vaccine administration, the delivery of vaccine antigens by APCs to activate and recruit $\mathrm{CD}^{+}{ }^{+} \mathrm{T}$ cells results in $\mathrm{T}$ and $\mathrm{B}$ cell interaction and the first step of the antibody response: B cell proliferation, maturation, and differentiation into plasma cells [40, 45]. However, the resulting antibodies have low affinity for the antigen, and the response is short-lived. This is followed by the effector phase of the response, which involves the production of higher-affinity antibodies by B cells, differentiation and proliferation of effector T cells [40], and generation of immunological memory, allowing a more rapid and efficient response when the target pathogen is encountered at a later time [37]. B cells are then involved in modulating the contraction of $\mathrm{CD}^{+}$T cell responses following immunization and in generating memory T cells [46]. Follicular T helper cells are integral to B cell activation or differentiation into memory and plasma cells and in the generation of long-lived antibody responses [66]. The role of follicular $\mathrm{T}$ helper cells in the response to vaccination is especially important in the context of therapies for MS that alter or deplete certain immune cell populations. If the follicular $\mathrm{T}$ helper cell response is suppressed, complete seroprotection is unlikely to be achieved with a vaccine or even repeated vaccination. Nevertheless, partial seroprotection could still be enough to prevent contracting the infection of interest and/or preventing severe complications from the infection.

The US Centers for Disease Control and Prevention frequently updates the recommendations for adults receiving routine 
vaccinations to prevent 17 vaccine-preventable diseases [67]. Recommendations are made on the basis of the effectiveness of the vaccines, which is assessed by humoral response (i.e., the presence of antigen-specific antibody titers) [68]. The hemagglutination inhibition assay, which measures the presence of antibodies to hemagglutinins (which are glycoproteins on the surface of influenza viruses), is one way to measure influenza vaccine response $[68,69]$. Typical outcomes seen in clinical trials for vaccines include assessment of antibody titers, seroconversion rates, seroprotection rates (percentages of people developing neutralizing antibodies), functional antibodies (by flow cytometric opsonophagocytosis assays), antibody avidity, B cell and T cell activation, lymphoproliferation, and cytokine responses [70].

However, systems for measuring cellular responses to vaccination are not typically utilized in clinical trials or clinical practice for a number of reasons, including the complexity and cost associated with such assays. For example, US Food and Drug Administration guidelines for influenza vaccine development rely on hemagglutination-inhibiting (HI) antibody titers, i.e., percentage of subjects achieving an $\mathrm{HI}$ antibody titer of at least 1:40 and rates of seroconversion (change in titer from less than $1: 10$ to at least $1: 40$ or fourfold rise in HI antibody titer) [71]. T cells have been demonstrated to play a role in the immune response to SARSCoV-2 [72, 73], but such responses are difficult to measure, which has prevented a full understanding of the role of $\mathrm{T}$ cells in an effective vaccine response against SARS-CoV-2. Because these data on cellular responses to vaccination are limited, the extent to which any one individual or group of individuals responds to vaccination is difficult to ascertain. In the future, systems biology may be used to analyze early human immune responses to vaccination. Using such approaches, individuals who have been vaccinated may display noticeable and characteristic changes in the gene expression profiles of their peripheral blood leukocytes, allowing for an understanding of the immune response beyond just antibody titers [74].

As treatment of MS evolves toward a personalized approach, immune correlates and how vaccine response is measured-including not only humoral immune responses but also cellular immune responses-may help determine the true differential impact of MS DMTs on vaccine immune response. Moreover, the management of MS may prove to be an incremental burden revolving around treatment choices and timing, if a yearly COVID-19 vaccine or booster becomes necessary.

Individuals may experience diminished protection from vaccines for various reasons. For example, inadequate responses have been reported in people aged over 64 years [75], which may result from immunosenescence stemming from thymic involution, a decrease in naïve $\mathrm{T}$ cells, increased $\mathrm{T}$ cell memory defects, and impaired ability of B cells to undergo class-switch recombination (i.e., isotype switching), resulting in less diversity of antibodies and decreases in naïve B cells [76]. Other factors that may affect response include sex, obesity, behavior, comorbidities, pregnancy, immunosuppression, and possibly ethnicity $[70,77,78]$. All of these considerations will apply to people with MS as well, and may impact vaccine responsiveness in this population.

\section{GUIDANCE AND GUIDELINES ON VACCINES FROM MS-RELATED SOCIETIES AND ORGANIZATIONS}

A number of organizations have made recommendations regarding vaccination for people with MS (Table 2) and, importantly, most point to the lack of high-quality data that can support recommendations [16-18]. The only recommendation by the American Academy of Neurology (AAN) based on the strongest level of evidence (level A) is to screen for certain infections, according to the prescribing information of the particular immunosuppressive or immunomodulating DMT being considered as treatment, and for latent infections in high-risk populations or in countries where specific infections are common [16].

A Delphi consensus statement from a panel of experts and the French Multiple Sclerosis Society (Société Francophone de la Sclérose en 
Table 2 Vaccine guidance and guidelines for people with MS

\begin{tabular}{|c|c|c|c|c|c|c|}
\hline Guidance/guideline & $\begin{array}{l}\text { AAN } \\
{[16,79]}\end{array}$ & $\begin{array}{l}\text { MSIF } \\
{[19]^{\mathrm{a}}}\end{array}$ & $\begin{array}{l}\text { NMSS } \\
{[14,15,80]^{\mathrm{b}}}\end{array}$ & $\begin{array}{l}\text { MSAA } \\
{[20]^{b}}\end{array}$ & $\begin{array}{l}\text { SFSEP } \\
{[17,81]^{\mathrm{c}}}\end{array}$ & $\begin{array}{l}A B N \\
{[82]^{d}}\end{array}$ \\
\hline \multicolumn{7}{|l|}{ Live attenuated and killed vaccines } \\
\hline Infection screening & $\checkmark$ & $\begin{array}{l}\text { No } \\
\text { guidance }\end{array}$ & $\boldsymbol{V}$ & $\checkmark$ & $\begin{array}{l}\text { No } \\
\text { guidance }\end{array}$ & $\begin{array}{l}\text { No } \\
\text { guidance }\end{array}$ \\
\hline $\begin{array}{l}\text { Discuss available information and } \\
\text { patients' opinions to determine optimal } \\
\text { strategy }\end{array}$ & $\boldsymbol{V}$ & $\begin{array}{l}\text { No } \\
\text { guidance }\end{array}$ & $\boldsymbol{V}$ & $\checkmark$ & $\begin{array}{l}\text { No } \\
\text { guidance }\end{array}$ & $\begin{array}{l}\text { No } \\
\text { guidance }\end{array}$ \\
\hline Follow all local vaccine standards $s^{e}$ & $\checkmark$ & $\begin{array}{l}\text { No } \\
\text { guidance }\end{array}$ & $\checkmark$ & $\checkmark$ & $\checkmark$ & $\begin{array}{l}\text { No } \\
\text { guidance }\end{array}$ \\
\hline $\begin{array}{l}\text { Influenza vaccination should be received } \\
\text { annually }\end{array}$ & $\checkmark$ & $\checkmark$ & $\boldsymbol{V}$ & $\boldsymbol{v}$ & $\checkmark$ & $\begin{array}{l}\text { No } \\
\text { guidance }\end{array}$ \\
\hline $\begin{array}{l}\text { Patients should be counseled about } \\
\text { infection risks associated with ISIM } \\
\text { therapy and ISIM-specific vaccination } \\
\text { guidance }\end{array}$ & $\checkmark$ & $\begin{array}{l}\text { No } \\
\text { guidance }\end{array}$ & $\checkmark$ & $\checkmark$ & $\checkmark$ & $\begin{array}{l}\text { No } \\
\text { guidance }\end{array}$ \\
\hline $\begin{array}{l}\text { Vaccination status should be assessed } \\
\text { before prescribing ISIM therapy }\end{array}$ & $\checkmark$ & $\begin{array}{l}\text { No } \\
\text { guidance }\end{array}$ & $\checkmark$ & $\boldsymbol{V}$ & $\checkmark$ & $\begin{array}{l}\text { No } \\
\text { guidance }\end{array}$ \\
\hline $\begin{array}{l}\text { Vaccination should occur } \geq 4-6 \text { weeks } \\
\text { before ISIM therapy initiation }^{f}\end{array}$ & $\checkmark$ & $\begin{array}{l}\text { No } \\
\text { guidance }\end{array}$ & $\boldsymbol{V}$ & $\checkmark$ & $\begin{array}{l}\text { No } \\
\text { guidance }\end{array}$ & $\begin{array}{l}\text { No } \\
\text { guidance }\end{array}$ \\
\hline $\begin{array}{l}\text { Live attenuated vaccines should be } \\
\text { avoided while on ISIM therapy or if } \\
\text { recently discontinued; if a patient is at } \\
\text { high risk of infection and killed } \\
\text { vaccines are unavailable, live attenuated } \\
\text { vaccines may be considered }\end{array}$ & $\checkmark$ & $\begin{array}{l}\text { No } \\
\text { guidance }\end{array}$ & $\checkmark$ & $\checkmark$ & $\boldsymbol{v}$ & $\begin{array}{l}\text { No } \\
\text { guidance }\end{array}$ \\
\hline $\begin{array}{l}\text { Vaccination during MS relapse should } \\
\text { be delayed }\end{array}$ & $\checkmark$ & $\begin{array}{l}\text { No } \\
\text { guidance }\end{array}$ & $\boldsymbol{V}$ & $\boldsymbol{V}$ & $\boldsymbol{⿰}^{\mathrm{g}}$ & $\begin{array}{l}\text { No } \\
\text { guidance }\end{array}$ \\
\hline \multicolumn{7}{|l|}{ COVID-19 mRNA vaccines ${ }^{\mathrm{h}}$} \\
\hline $\begin{array}{l}\text { Discuss available information and } \\
\text { patients' opinions to determine optimal } \\
\text { strategy }\end{array}$ & $\begin{array}{l}\text { No } \\
\text { guidance }\end{array}$ & $\checkmark$ & $\boldsymbol{V}^{\mathrm{i}}$ & $\begin{array}{l}\text { No } \\
\text { guidance }\end{array}$ & $\begin{array}{l}\text { No } \\
\text { guidance }\end{array}$ & $\boldsymbol{V}^{\mathrm{d}}$ \\
\hline $\begin{array}{l}\text { Most people with MS should be } \\
\text { vaccinated; vaccination unlikely to } \\
\text { trigger MS relapse or worsen chronic } \\
\text { symptoms }\end{array}$ & $\begin{array}{l}\text { No } \\
\text { guidance }\end{array}$ & $\checkmark$ & $\checkmark$ & $\begin{array}{l}\text { No } \\
\text { guidance }\end{array}$ & $\begin{array}{l}\text { No } \\
\text { guidance }\end{array}$ & $\boldsymbol{\nu}^{\mathrm{d}}$ \\
\hline $\begin{array}{l}\text { Vaccination can occur while on ISIM } \\
\text { therapy }\end{array}$ & $\begin{array}{l}\text { No } \\
\text { guidance }\end{array}$ & $\checkmark$ & $\boldsymbol{V}^{\mathrm{h}}$ & $\begin{array}{l}\text { No } \\
\text { guidance }\end{array}$ & $\checkmark$ & $\boldsymbol{\sigma}^{\mathrm{d}}$ \\
\hline
\end{tabular}


Table 2 continued

\begin{tabular}{|c|c|c|c|c|c|c|}
\hline Guidance/guideline & $\begin{array}{l}\text { AAN } \\
{[16,79]}\end{array}$ & $\begin{array}{l}\text { MSIF } \\
{[19]^{\mathrm{a}}}\end{array}$ & $\begin{array}{l}\text { NMSS } \\
{[14,15,80]^{b}}\end{array}$ & $\begin{array}{l}\text { MSAA } \\
{[20]^{\mathbf{b}}}\end{array}$ & $\begin{array}{l}\text { SFSEP } \\
{[17,81]^{\mathrm{c}}}\end{array}$ & $\begin{array}{l}\mathrm{ABN} \\
{[82]^{\mathrm{d}}}\end{array}$ \\
\hline $\begin{array}{l}\text { Both doses of vaccine should be taken, } \\
\text { even if side effects temporarily } \\
\text { exacerbate MS symptoms }\end{array}$ & $\begin{array}{l}\text { No } \\
\text { guidance }\end{array}$ & $\boldsymbol{V}$ & $\checkmark$ & $\begin{array}{l}\text { No } \\
\text { guidance }\end{array}$ & $\begin{array}{l}\text { No } \\
\text { guidance }\end{array}$ & $\boldsymbol{V}^{\mathrm{d}}$ \\
\hline $\begin{array}{l}\text { Data to support evidence-based } \\
\text { recommendations on the implications } \\
\text { of vaccination for specific neurologic } \\
\text { diseases are not yet available }\end{array}$ & $\boldsymbol{V}$ & $\boldsymbol{v}$ & $\checkmark$ & $\begin{array}{l}\text { No } \\
\text { guidance }\end{array}$ & $\boldsymbol{v}$ & $\boldsymbol{V}^{\mathrm{d}}$ \\
\hline
\end{tabular}

AAN American Academy of Neurology, ABN Association of British Neurologists, ISIM immunosuppressive or immunomodulating, MS multiple sclerosis, MSIF Multiple Sclerosis International Federation, NMSS National Multiple Sclerosis Society, Multiple Sclerosis Association of America, SIP sphingosine-1-phosphate, SFSEP Société Francophone de la Sclérose En Plaques (French Multiple Sclerosis Society)

a COVID-19 mRNA vaccine guidance relates to Pfizer-BioNTech and Moderna

b Refers to AAN guidelines on live attenuated and killed vaccines

${ }^{c}$ Guidance is associated with immunosuppressive therapy, but no restrictions on vaccination associated with immunomodulators are indicated

${ }^{\mathrm{d}}$ Recommendations are not specific for MS

${ }^{\mathrm{e}}$ Unless there is a specific contraindication

${ }^{\mathrm{f}}$ According to local regulatory standards, guided by treatment-specific infectious risks, and as advised by specific prescribing information

${ }^{g}$ If relapse treatment requires high-dose steroid therapy

${ }^{\mathrm{h}}$ Information current as of February 11, 2021

${ }^{i}$ NMSS guidance on timing of medications [80]: S1P receptor modulators: consider getting fully vaccinated (defined as 2 doses of the mRNA [Pfizer BioNTech or Moderna] or 1 dose of the vector vaccine [Janssen]) $\geq 2-4$ weeks before starting. If already on an S1P receptor modulator, continue medication and get vaccinated when a vaccine is available. Alemtuzumab: consider getting fully vaccinated $\geq 4$ weeks before starting. If already on alemtuzumab, wait $\geq 24$ weeks after the last dose of alemtuzumab before getting vaccinated. If due for next treatment course, when possible, resume alemtuzumab $\geq 4$ weeks or more after getting fully vaccinated. Cladribine: consider getting fully vaccinated $\geq 2-4$ weeks before starting. If due for the next cladribine treatment, resume cladribine $2-4$ weeks after getting fully vaccinated. Ocrelizumab/rituximab: consider getting fully vaccinated $\geq 2-4$ weeks before starting treatment. If already on ocrelizumab or rituximab, consider getting fully vaccinated $\geq 12$ weeks after the last dose. When possible, resume ocrelizumab or rituximab $\geq 4$ weeks after getting fully vaccinated. Ofatumumab: consider getting fully vaccinated $\geq 2-4$ weeks before starting treatment. If already on ofatumumab, when possible resume ofatumumab 2-4 weeks after getting fully vaccinated. High-dose steroids: consider getting the vaccine injection(s) 3-5 days after the last dose

Plaques) agree with AAN regarding limited studies; and the French Multiple Sclerosis Society recommendations regarding preventative methods are generally similar to those of AAN $[17,18]$. The National Multiple Sclerosis Society and Multiple Sclerosis Association of America currently reference AAN and US Centers for Disease Control and Prevention guidance and guidelines and use language from DMT product labels regarding vaccination recommendations $[15,20]$.

Although robust data to support evidencebased recommendations on COVID-19 vaccinations are not yet available, the Multiple Sclerosis International Federation and the National Multiple Sclerosis Society have 
recently advised vaccination for most people with MS, which can occur while treatment with DMTs is ongoing $[14,19,79]$. Both have also recently made recommendations regarding the timing of DMTs with COVID-19 vaccination (Table 2) $[19,80]$.

These COVID-19 vaccination guidance and guidelines are living documents based on what has been learned from previous vaccine studies, DMT prescribing information, ongoing studies and registries such as the COViMS registry, and expert consensus, and will be updated over time as more data become available and as more vaccines are approved for use.

\section{VACCINE EFFICACY AND DMTS}

Because DMTs have immunosuppressive and/or immunomodulating effects, data on vaccination efficacy in people with MS treated with DMTs may help inform how the immune response may be impacted and whether there should be considerations about optimal timing of vaccine administration with DMTs. Most reports have been on the response to influenza vaccination. People with MS are able to mount a cellular immune response following influenza vaccination [83]. However, increases in influenza-specific $\mathrm{T}$ cells following vaccination are higher in people with MS than in healthy controls and, importantly, no increases in T cell responses to central nervous system myelin proteins (i.e., human myelin basic protein or recombinant human myelin oligodendrocyte protein) were seen [83]. A meta-analysis of studies on influenza vaccination in patients with MS found no statistical difference in immune responses versus healthy controls and that most immunotherapies did not affect the immune response [84].

As previously mentioned, the different mechanisms of action for DMTs (summarized in Table 3) have been shown to impact immune responses to vaccination with administration of different DMTs. This has been demonstrated in clinical studies, case reports, and some preclinical data (Table 4). Several reports on interferon beta products indicate that people with MS treated with interferon beta can generate protective levels of response to influenza, tetanus-diphtheria toxoid, pneumococcal vaccine polyvalent, and meningococcal vaccines [85-90], with no evidence for a reduction in tetanus toxoid-induced $\mathrm{T}$ cell responses [91]. Endogenous interferon betas are part of the type I interferon family, which play an important role in antiviral response [92, 93]. The binding of interferons to their receptors causes a signaling cascade leading to upregulation of genes that results in production of antiviral molecules such as myxovirus resistance proteins, adenosine deaminase acting on RNA (ADAR1), oligoadenylate synthetase, and RNase L nuclease [93-96]. Postmarketing surveillance data showing no increased risk of infection suggest therapeutic interferon betas may have some protective antiviral effects [97].

For all other DMTs, data suggest a diminished immune response to vaccination, usually influenza vaccination. Glatiramer acetate may also impact the immune response, though most studies indicate adequate responses $[87,130,131]$; in one study, patients on glatiramer acetate had slightly lower responses to influenza vaccination compared with healthy controls [90]. Teriflunomide was found to cause a mild dose-dependent reduction in the efficacy of influenza and rabies vaccines [86, 134]; higher doses of teriflunomide induced a lower response to at least one strain of influenza in the vaccines [86].

Among sphingosine-1-phosphate (S1P) receptor modulators, most data were available for fingolimod. Patients treated with fingolimod had reduced response rates to influenza vaccination versus patients treated with interferon or placebo or versus healthy controls and no increase in avidity (binding) of influenza-specific immunoglobulin (Ig) $G$ was seen [87, 130, 136, 137]. Studies and case reports also indicate that fingolimod affected responses to varicella zoster and pneumococcal polysaccharide vaccines [138-141]. The few data available for the other S1P receptor modulators, including a pooled analysis of two trials of ozanimod $(n=2659)$, suggest similar reductions in responses to vaccination $[145,146]$.

A study on dimethyl fumarate found adequate seroprotection and no reduction in 


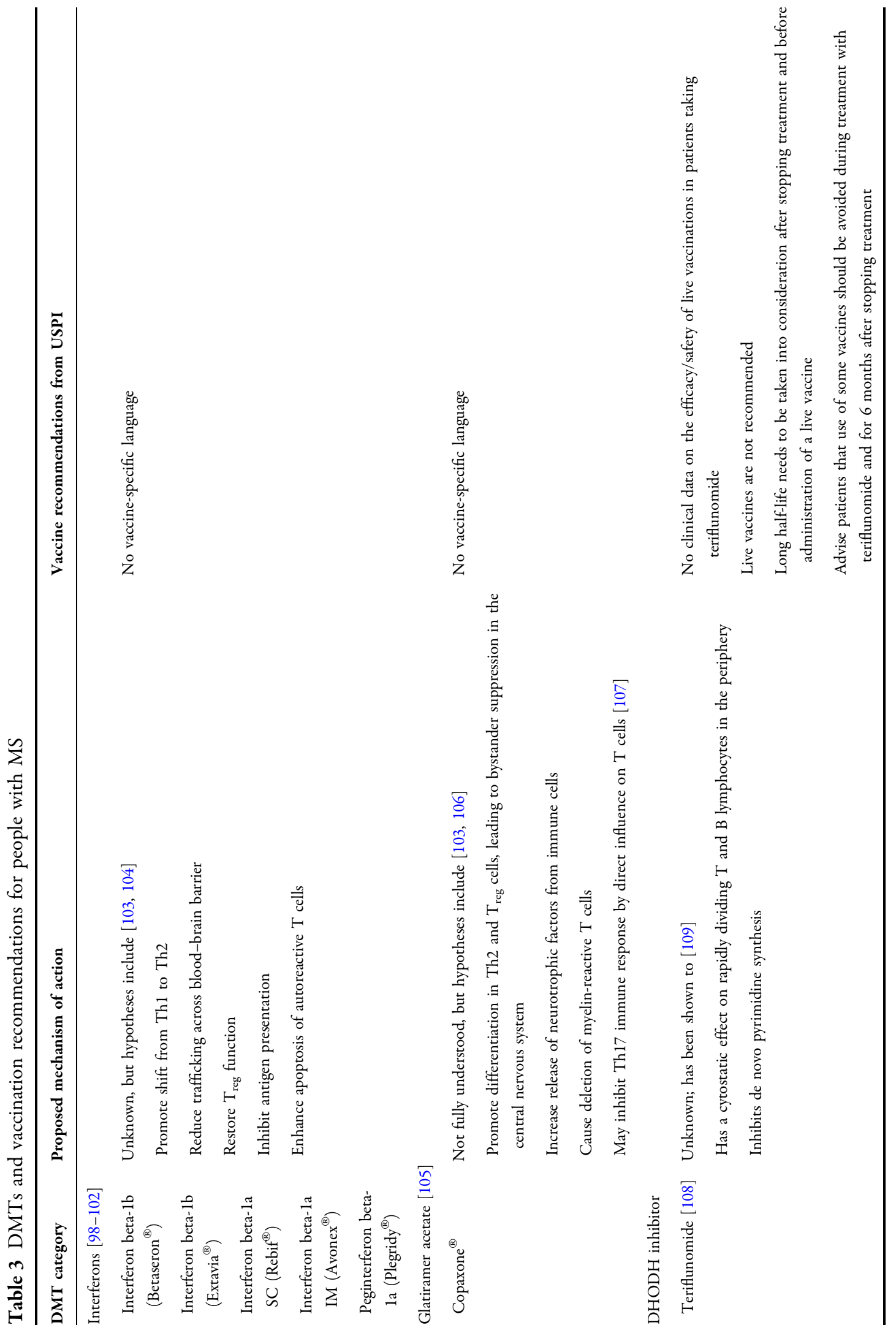




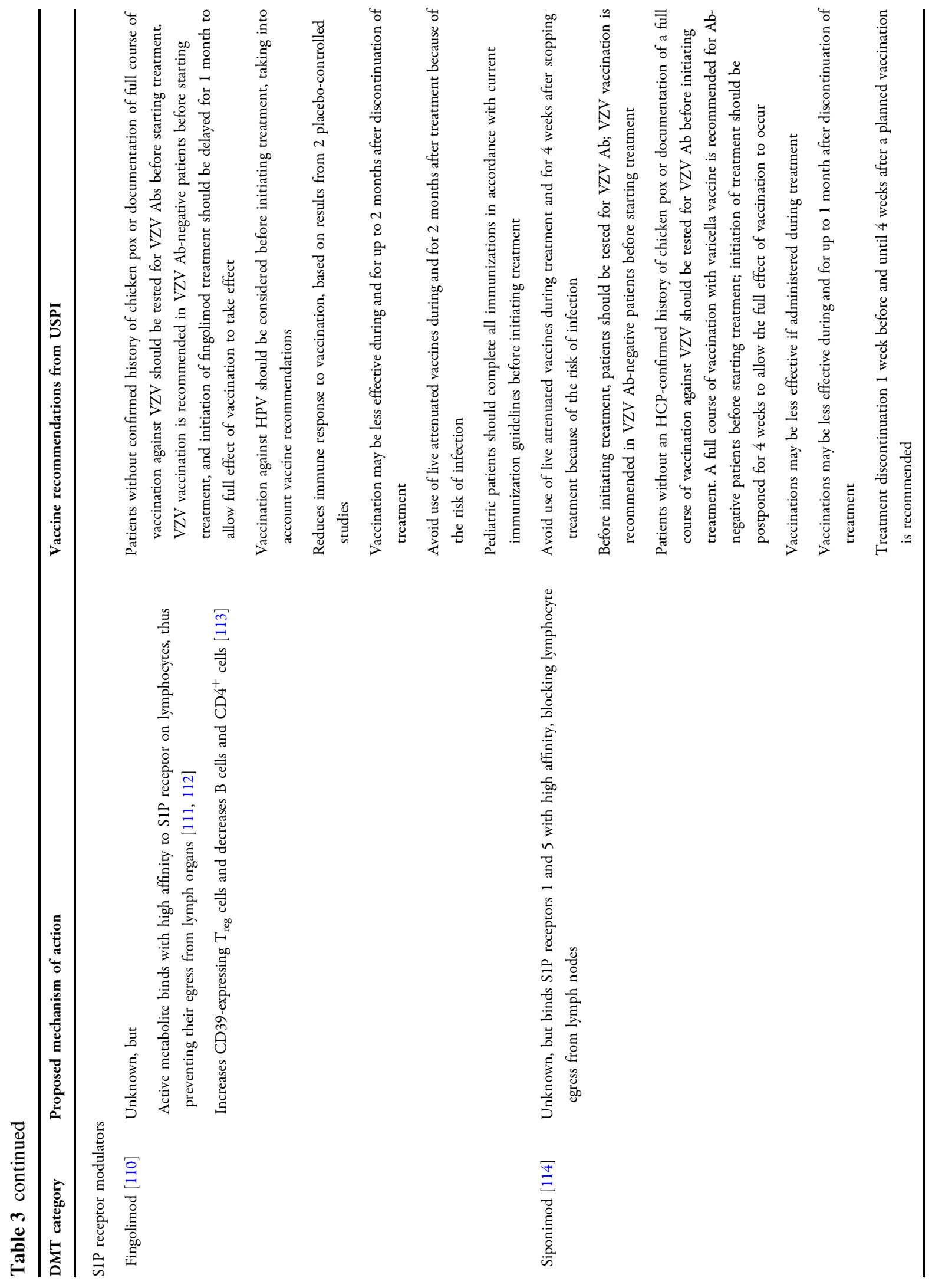




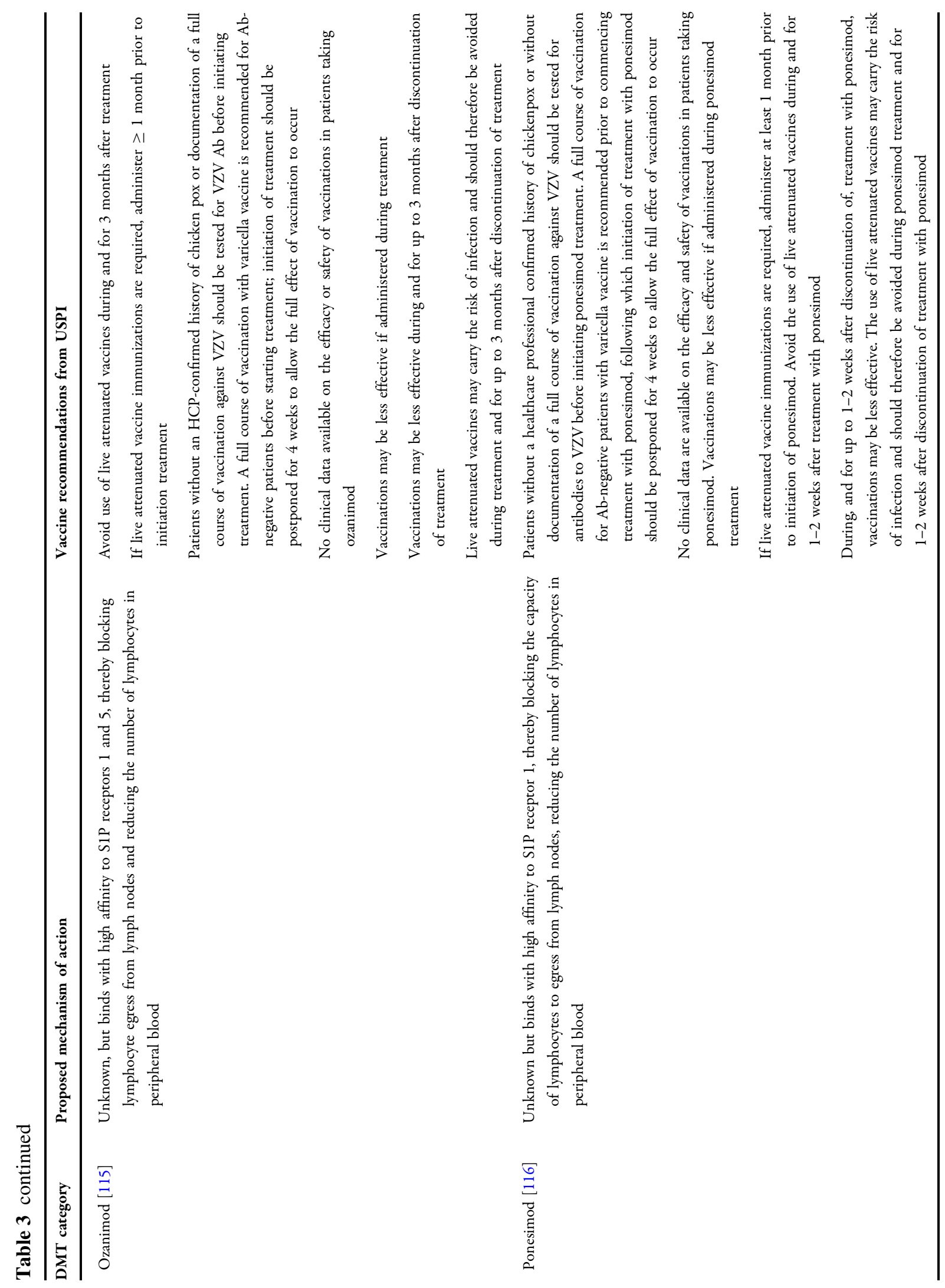




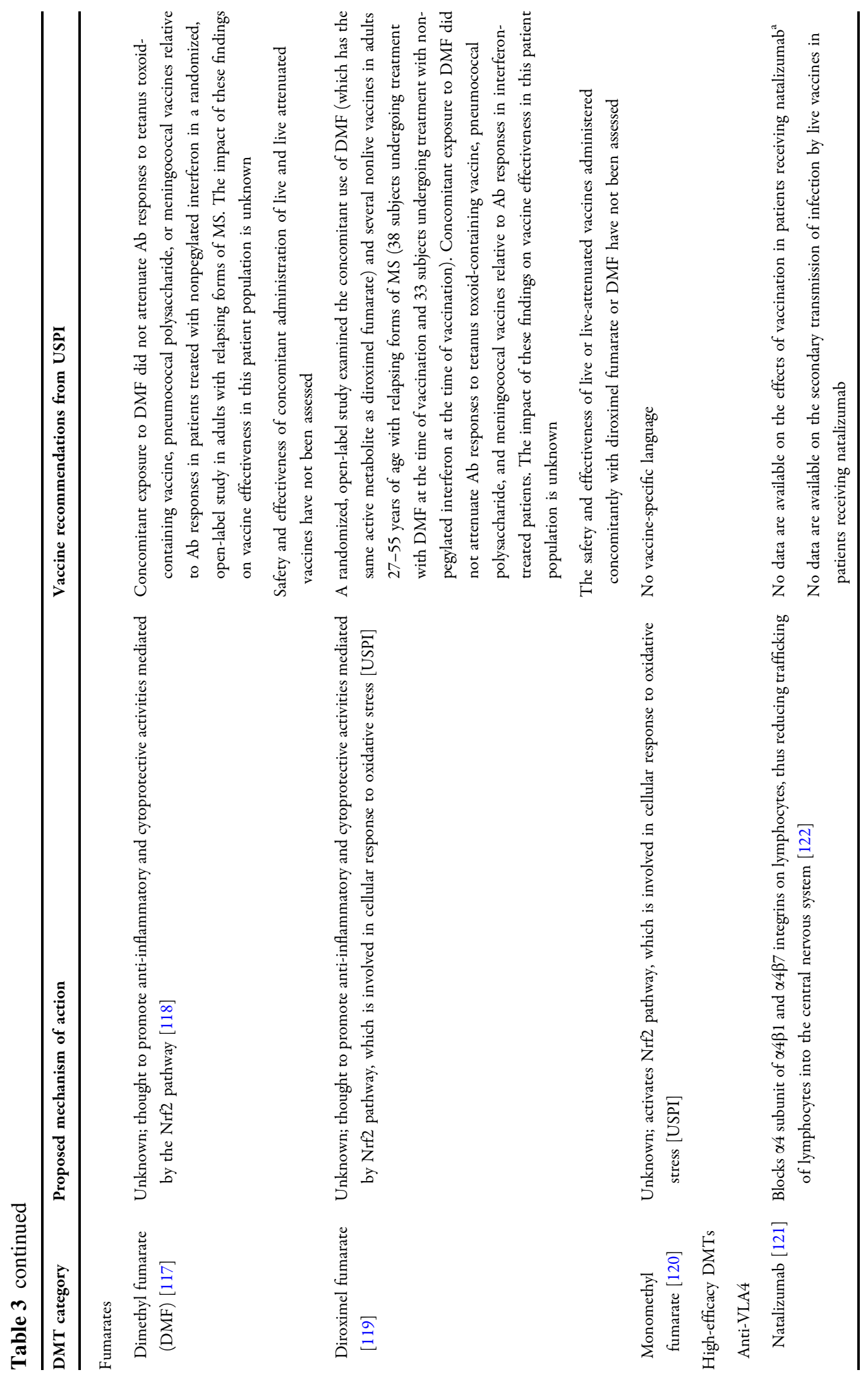




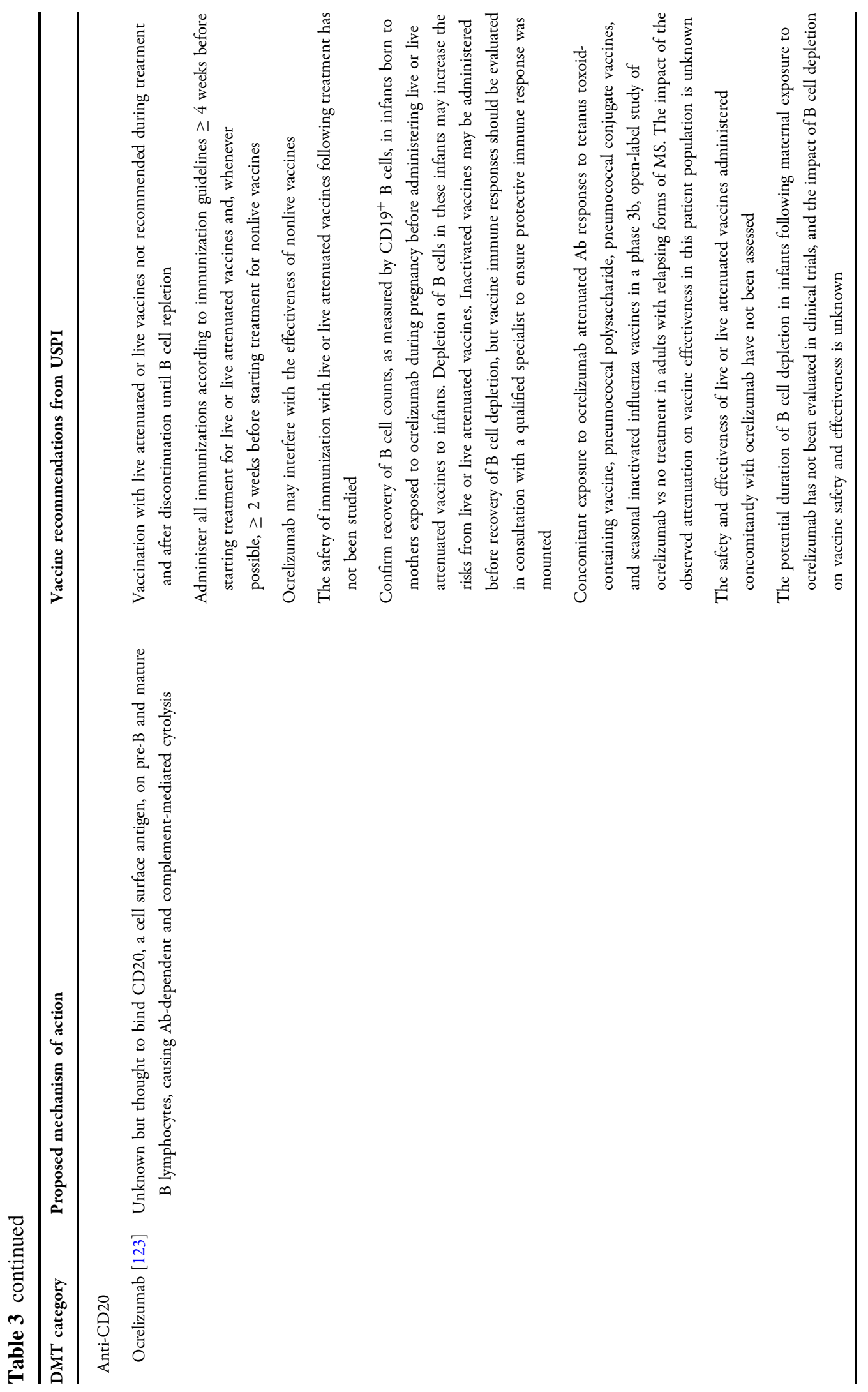




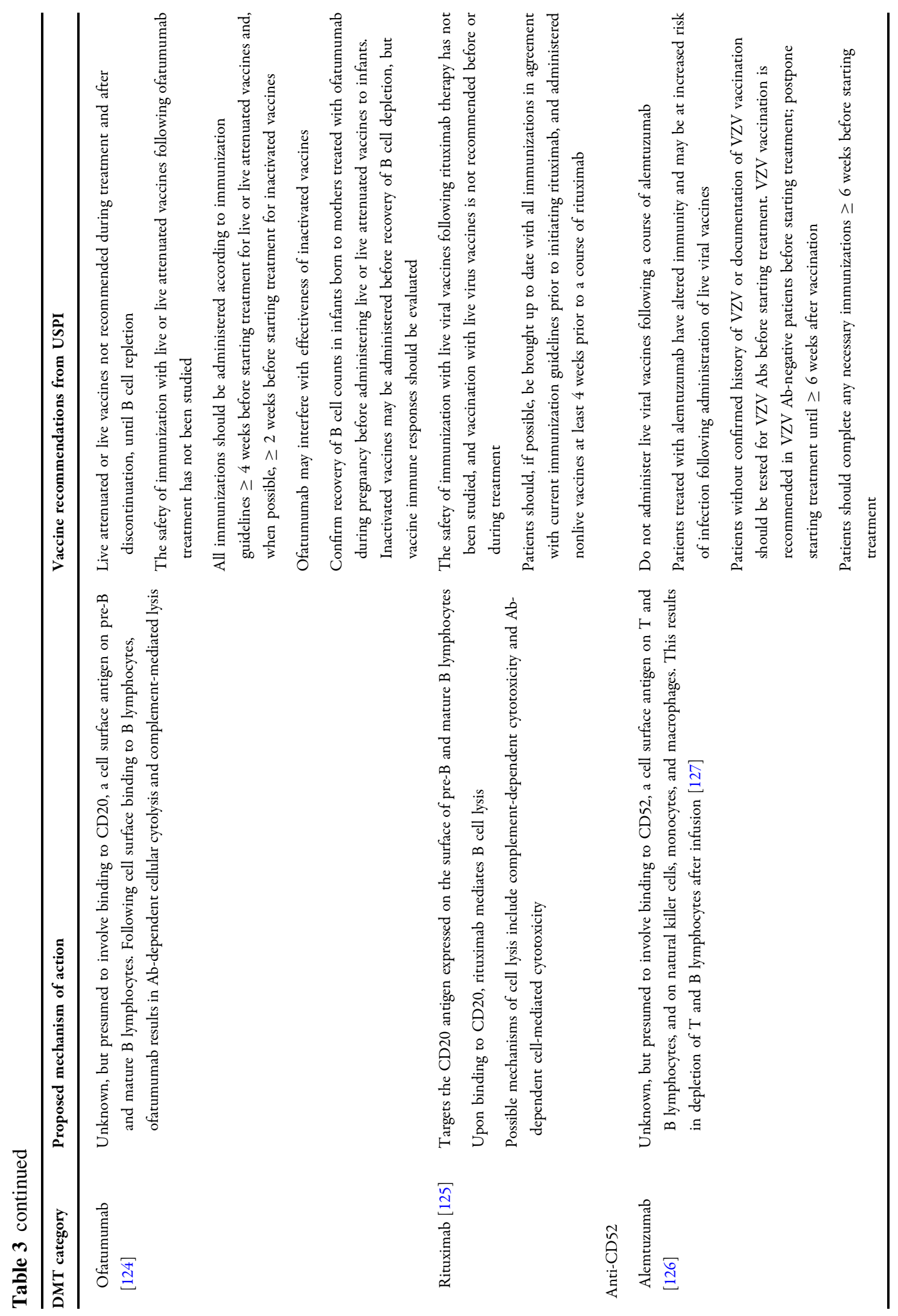




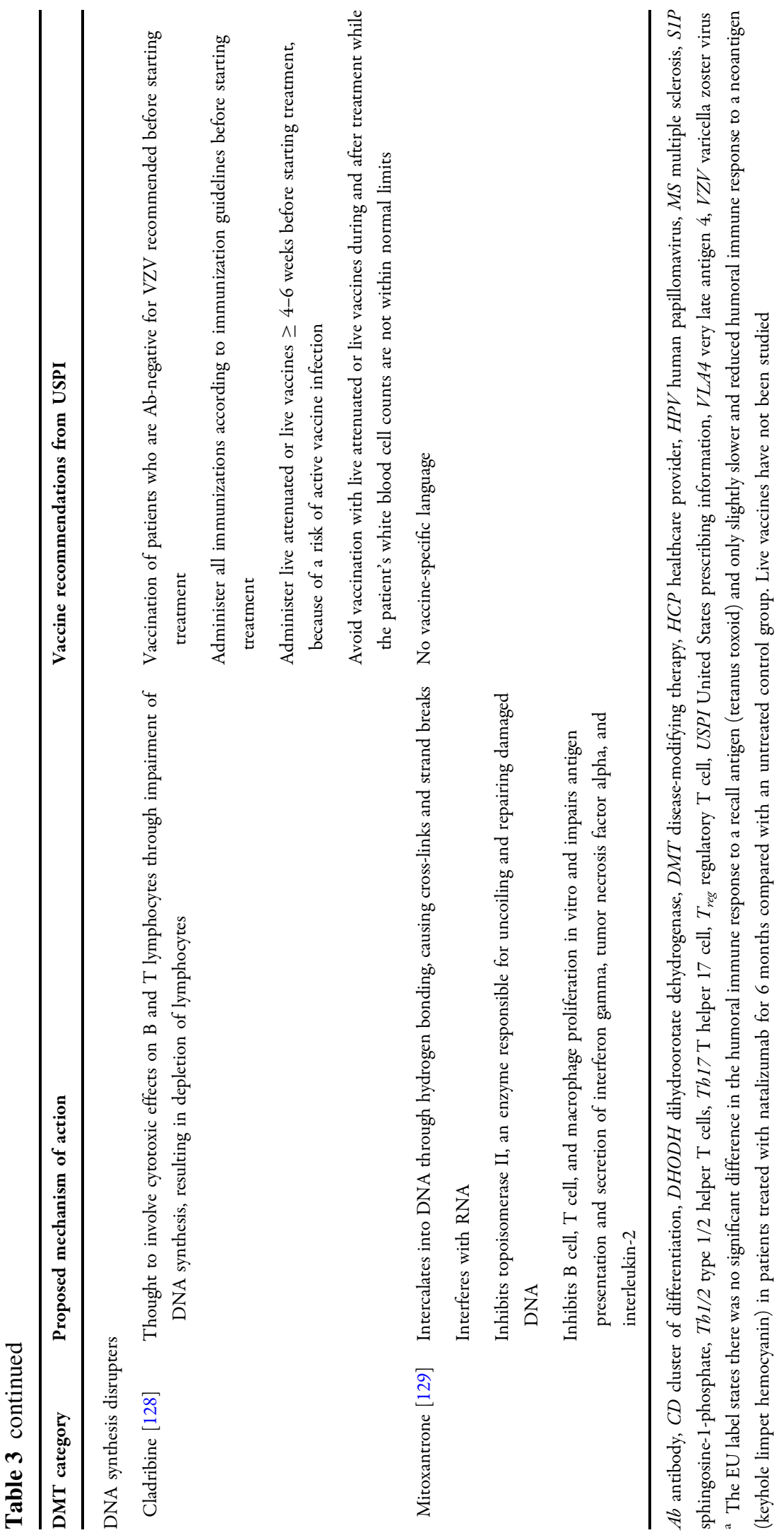




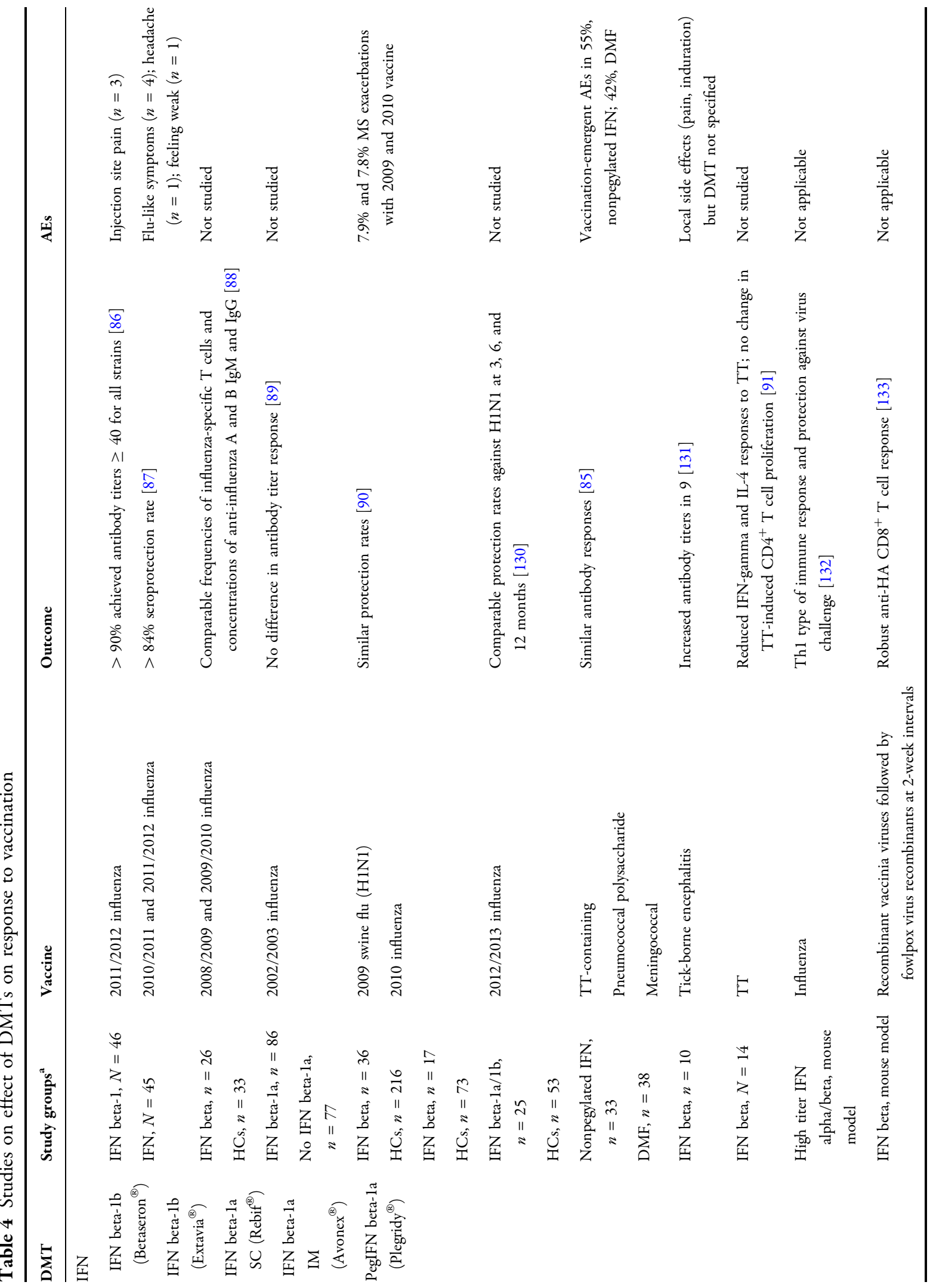




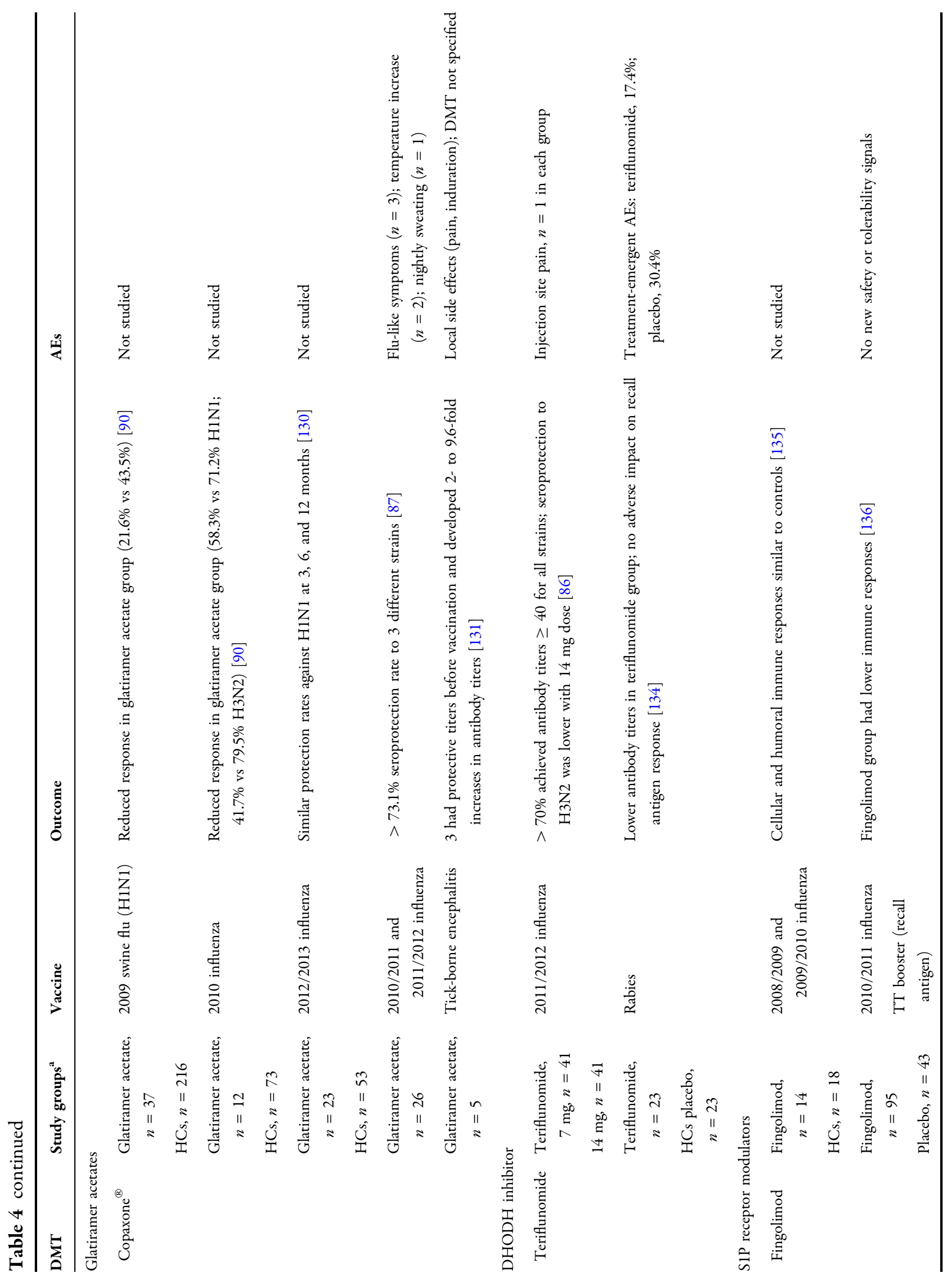




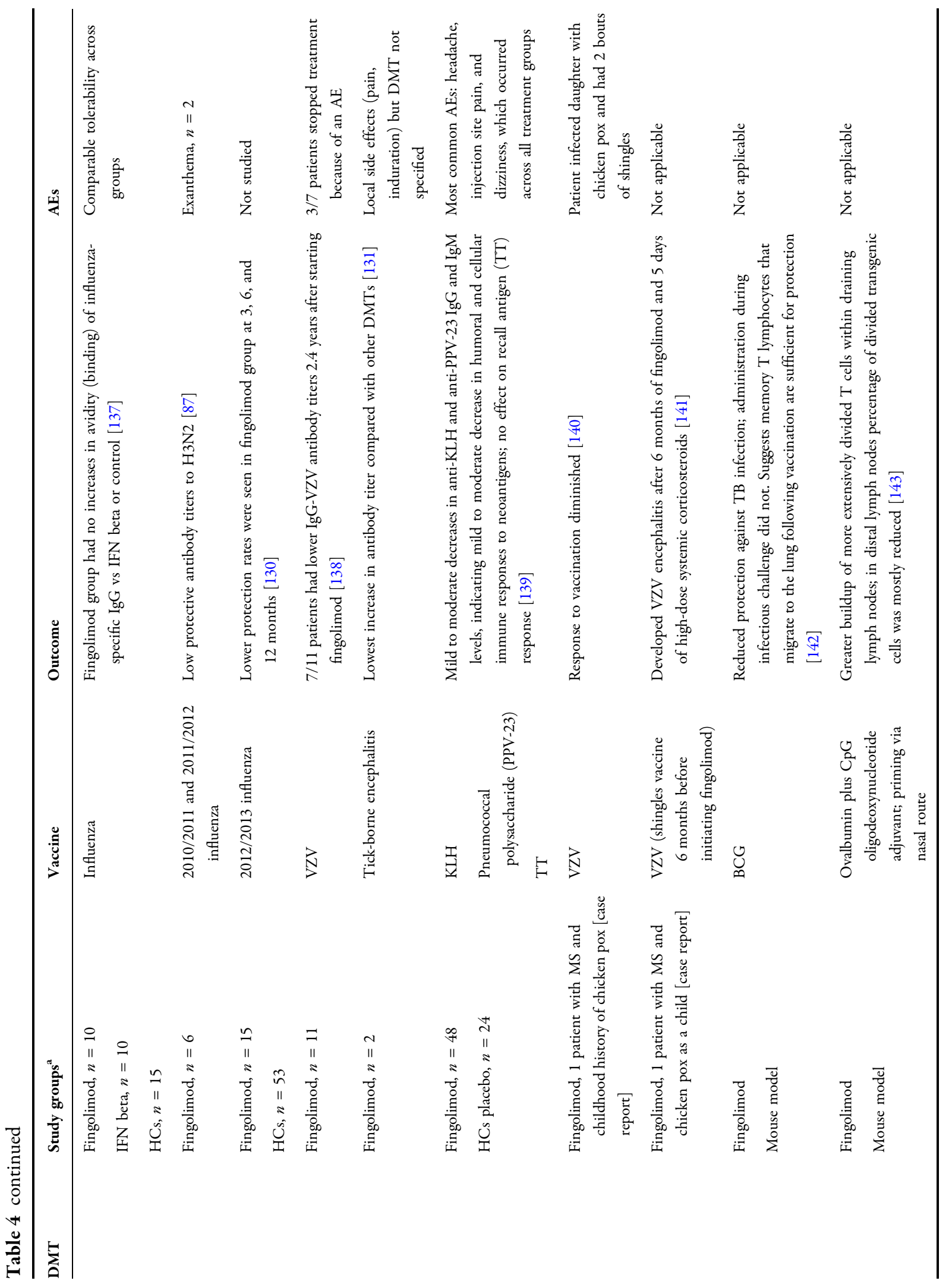




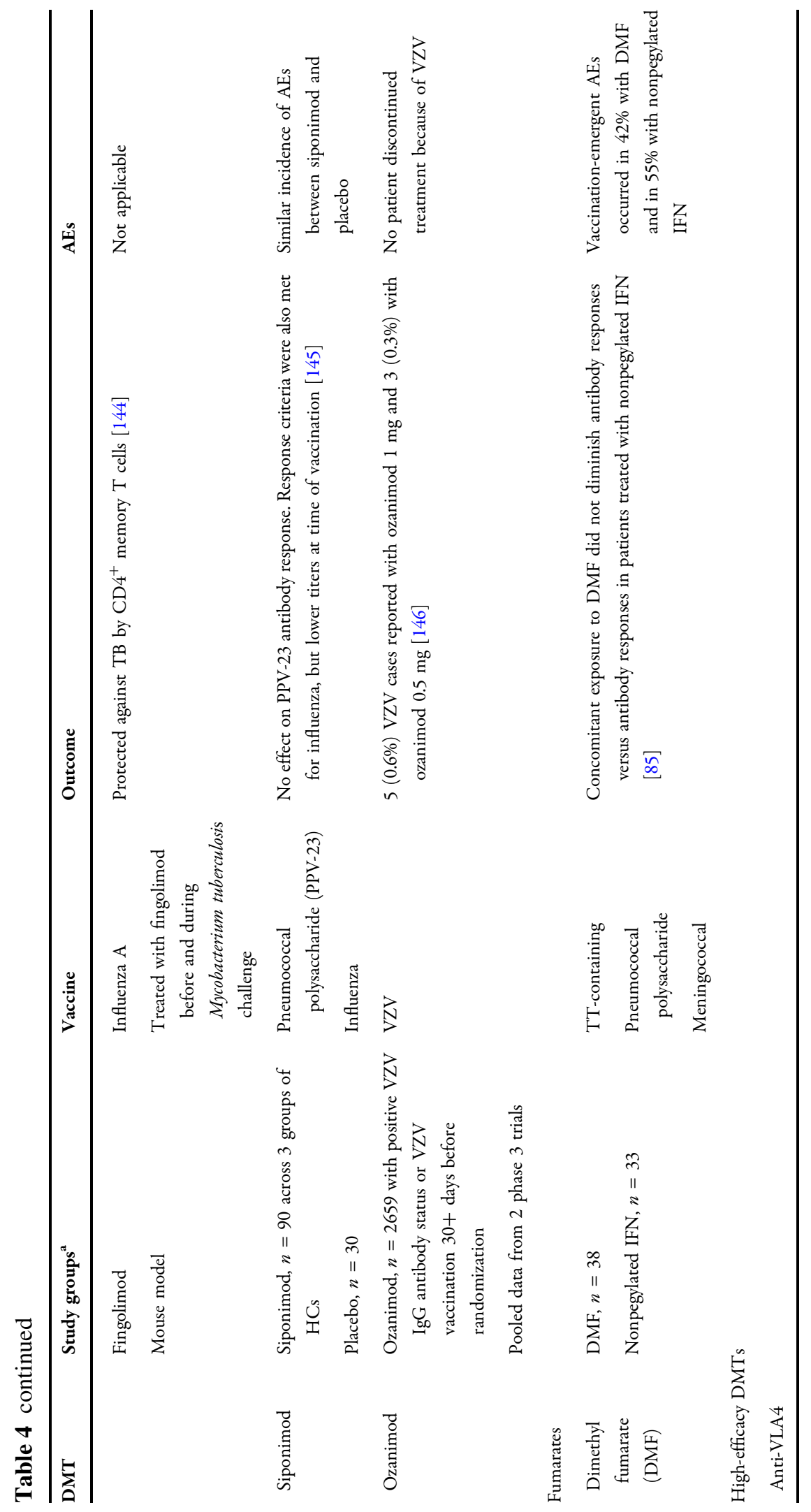




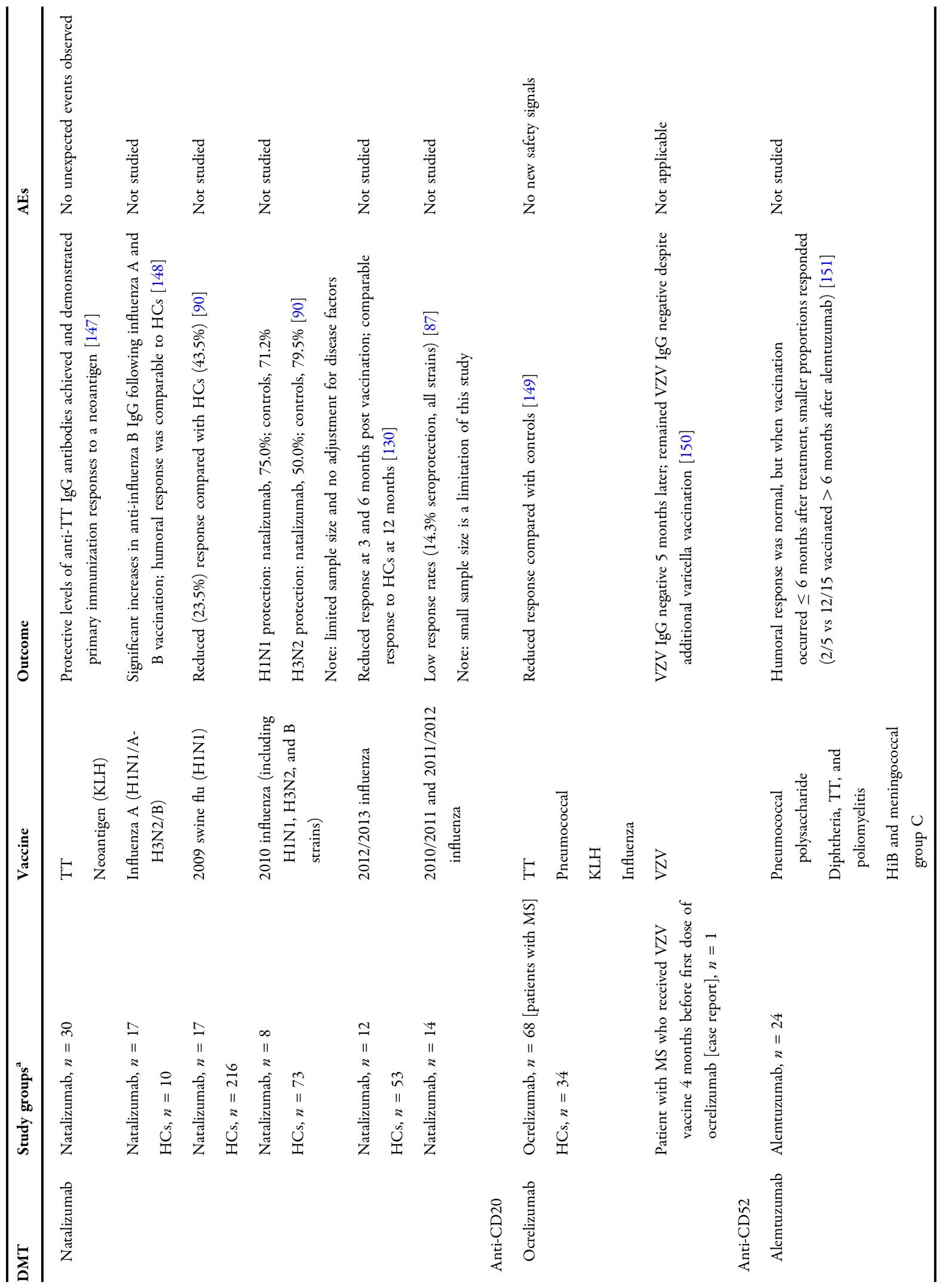


i- $\quad$ mmune responses to tetanus toxoid, pneumococcal polysaccharide, or meningococcal vaccines compared with interferon [85]. In addition, in the 96-week PROCLAIM study, antibody (IgA, IgG, IgM, and IgG1-4) subclass levels were stable with long-term (96-week) dimethyl fumarate treatment, though lymphocyte levels decreased (i.e., naïve $\mathrm{CD}^{+}$and $\mathrm{CD}^{+}$T cell increases, $\mathrm{CD}^{+}$and $\mathrm{CD}^{+}$central and effector memory $T$ cell decreases) [152]. This indicated a shift from an inflammatory to an anti-inflammatory cell profile without impairment of humoral immunity [152]. No data were available for the other fumarates.

Some information was available for several high-efficacy DMTs in people with MS. A randomized controlled study in patients with MS treated with natalizumab showed that all evaluated patients achieved protective levels of antitetanus toxin IgG antibodies, and a slightly lower proportion of responders to primary immunization with keyhole limpet hemocyanin with natalizumab compared to control group, suggesting that natalizumab may not significantly influence responses to primary or secondary immunization [147]. In several small studies, patients with MS treated with natalizumab achieved either comparable or lower responses to influenza vaccination versus those treated with interferons or versus healthy controls depending on the strain [87, 90, 130]. Although the studies were limited by small sample sizes with no adjustment for disease factors in the patients with MS, the responses were generally considered more than adequate to achieve seroprotection.

In a large study in patients with MS $(N=102)$, those treated with ocrelizumab were found to have substantially impaired responses to tetanus toxoid, influenza, and pneumococcal vaccines and to the neoantigen keyhole limpet hemocyanin compared with controls on interferon beta or no DMT [149]. Despite these attenuated immune responses, patients still mounted a humoral response, and the authors concluded that an adequate vaccine response is generated after ocrelizumab treatment that is seroprotective [149]. On the basis of these data, there may be an optimal timing of vaccine administration with this DMT. In phase 3 trials, 
Table 5 Major COVID-19 vaccines in use or in development

\begin{tabular}{|c|c|c|c|c|}
\hline Vaccine & Description & Administration & Efficacy (primary endpoint) & Safety \\
\hline $\begin{array}{l}\text { BNT162b2 } \\
\text { (Pfizer/ } \\
\text { BioNTech) }\end{array}$ & $\begin{array}{l}\text { LNP-encapsulated mRNA } \\
\text { encoding SARS-CoV-2 spike } \\
\text { protein modified by } 2 \text { proline } \\
\text { mutations }[168]\end{array}$ & $\begin{array}{c}\text { Two } 30-\mu \mathrm{g} \text { doses, } \\
21 \text { days apart } \\
{[169,171]}\end{array}$ & $\begin{array}{l}95.0 \% \text { efficacy } \geq 7 \text { days after dose } \\
2\left(N=36,523^{\mathrm{a}}\right): \text { COVID-19 } \\
\text { illness occurred in } 162 / 18,325 \\
\text { with placebo vs } 8 / 18,198 \text { with } \\
\text { BNT162b2 [171] }\end{array}$ & 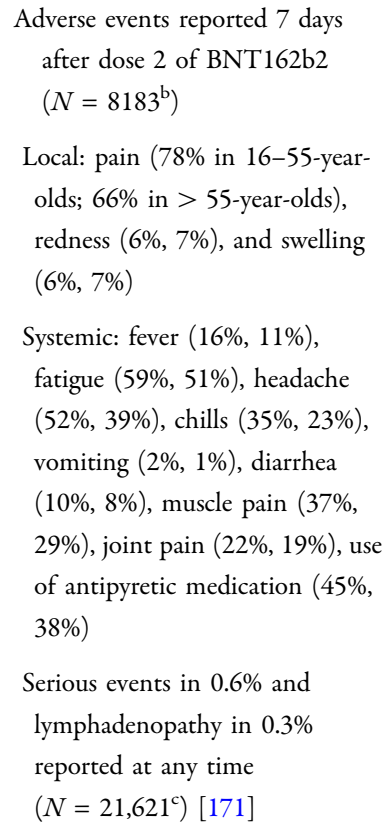 \\
\hline $\begin{array}{r}\text { mRNA-1273 } \\
\text { (Moderna) }\end{array}$ & $\begin{array}{l}\text { LNP-encapsulated mRNA } \\
\text { encoding SARS-CoV-2 spike } \\
\text { protein altered by } 2 \text { proline } \\
\text { substitutions [53] }\end{array}$ & $\begin{array}{l}\text { Two } 100-\mu \mathrm{g} \text { doses, } \\
28 \text { days apart } \\
{[169,170]}\end{array}$ & $\begin{array}{l}94.1 \% \text { efficacy }(p<0.001) \text { at } \\
14 \text { days after dose } 2 \\
\left(N=28,207^{\mathrm{d}}\right) \text { : COVID-19 } \\
\text { illness occurred in } 185 / 14,073 \\
\text { with placebo vs } 11 / 14,134 \text { with } \\
\text { mRNA-1273 [170] }\end{array}$ & $\begin{array}{l}\text { Solicited adverse reactions } \\
\text { (grade 3) reported } 7 \text { days after } \\
\text { dose } 2 \text { of mRNA-1273 } \\
\left(N=14,677^{\mathrm{e}}\right)[170] \\
\text { Local: pain }(4.1 \%) \text {, erythema } \\
(2.0 \%) \text {, swelling (1.7\%), axillary } \\
\text { swelling/tenderness }(0.5 \%) \\
\text { Systemic (grade } 3 / 4) \text { : fever }(1.4 \% / \\
<0.1 \%), \text { headache }(4.5 \% / 0 \%) \text {, } \\
\text { fatigue }(9.7 \% / 0 \%) \text {, myalgia } \\
(9.0 \% / 0 \%), \text { arthralgia }(5.2 \% / \\
0 \%), \text { nausea/vomiting }(0.1 \% / \\
<0.1 \%) \text {, chills }(1.3 \% / 0 \%) \\
\text { Bell's palsy }{ }^{\mathrm{f}} \text { in } 3 \text { vaccine } \\
\text { recipients }>28 \text { days after } \\
\text { injection }\end{array}$ \\
\hline
\end{tabular}


Table 5 continued

\begin{tabular}{|c|c|c|c|c|}
\hline Vaccine & Description & Administration & Efficacy (primary endpoint) & Safety \\
\hline $\begin{array}{l}\text { Ad26.COV2.S } \\
\text { (VAC31518; } \\
\text { JNJ- } \\
\text { 78436735; } \\
\text { Janssen } \\
\text { Biotech) }\end{array}$ & $\begin{array}{l}\text { Recombinant replication-deficient } \\
\text { adenovirus vector vaccine } \\
\text { encoding SARS-CoV-2 spike } \\
\text { protein gene altered by } 2 \\
\text { proline substitutions }[58,59]\end{array}$ & $\begin{array}{l}\text { One } 0.5 \text {-mL dose, } \\
\quad 5 \times 10^{10} \mathrm{vp}\end{array}$ & $\begin{array}{l}\text { 66.9\% efficacy at } 14 \text { days after } \\
\text { administration }\left(N=39,321^{\mathrm{g}}\right) \\
\text { [59]: COVID-19 illness } \\
\text { (PCR+; moderate to } \\
\text { severe/critical) in } 348 / 19,544 \\
\text { with placebo vs } 116 / 19,514 \text { with } \\
\text { Ad26.COV2.S }\end{array}$ & $\begin{array}{l}\text { Solicited AEs (grade } 3) \text { up to } \\
28 \text { days after administration of } \\
\text { Ad26.COV2.S }\left(N=3356^{\mathrm{h}}\right) \\
\text { [59]: erythema }(0.2 \%) \text {, pain } \\
(0.3 \%) \text {, swelling }(0.2 \%) \text {, fatigue } \\
(0.1 \%) \text {, headache }(0.7 \%) \text {, } \\
\text { myalgia }(1.0 \%) \text {, nausea }(0.2 \%) \text {, } \\
\text { pyrexia }(0.2 \%) \text {; no grade } 4 \\
\text { solicited AEs } \\
\text { Serious AEs of special interest/ } \\
\text { related to vaccine: facial paralysis } \\
(n=2) \text {, brachial radiculitis } \\
(n=1) \text {, Guillain-Barré } \\
\text { syndrome }(n=1) \text {, transverse } \\
\text { sinus thrombosis }(n=1), \\
\text { postvaccination syndrome } \\
(n=1) \\
\text { No severe anaphylactic reactions } \\
\text { were reported in any study }\end{array}$ \\
\hline $\begin{array}{l}\text { ChAdOx1 } \\
\text { nCoV-19 } \\
\text { (AZD12222; } \\
\text { AstraZeneca } \\
\text { and Oxford } \\
\text { Vaccine } \\
\text { Group) }\end{array}$ & $\begin{array}{l}\text { Single recombinant, replication- } \\
\text { deficient adenovirus vector } \\
\text { vaccine encoding unmodified } \\
\text { SARS-CoV-2 spike protein } \\
\text { [57] }\end{array}$ & $\begin{array}{l}\text { Two } 0.5 \text {-mL doses, } \\
28-84 \text { days apart; } \\
\text { each dose } \\
\text { contains } \\
2.5 \times 10^{8} \\
\text { infectious units } \\
{[57]}\end{array}$ & $\begin{array}{l}70.4 \% \text { efficacy at } 14 \text { days in all } \\
\text { participants }\left(N=11,636^{\mathrm{i}}\right) \text { : } \\
\text { COVID illness in } 101 / 5829 \\
\text { with placebo and } 30 / 5807 \text { with } \\
\text { ChAdOx } 1 \mathrm{nCoV}-19[172] \\
62.1 \% \text { efficacy at } 14 \text { days in } \\
\text { participants }(n=8895) \text { who } \\
\text { received } 2 \text { standard doses } \\
\left(5 \times 10^{10} \mathrm{vp}\right) \\
90.0 \% \text { efficacy in participants } \\
(n=2741) \text { who received } 1 \text { low } \\
\text { dose }\left(2.5 \times 10^{10} \mathrm{vp}\right) \text { and } 1 \\
\text { standard dose }\end{array}$ & $\begin{array}{l}\text { AE at any time during study with } \\
\text { ChAdOx1 nCoV-19 } \\
\left(N=12,021^{j}\right)[172] \\
\text { Any serious AE }(n=79 ; 0.7 \%) \\
\text { including diarrhea } \\
\text { ( } n=1 ;<0.1 \%) \text {, pain }(0), \\
\text { pyrexia }(n=1 ;<0.1 \%), \\
\text { vomiting ( } n=1 ;<0.1 \%) \\
\text { AEs of special interest: } \\
\text { anaphylactic reaction } \\
(n=1 ;<0.1 \%), \text { neuralgia } \\
\text { (n=2; }<0.1 \%), \text { neuritis } \\
(n=1 ;<0.1 \%), \text { neuropathy } \\
\text { peripheral }(n=1 ;<0.1 \%), \\
\text { facial paralysis }(n=3 ;<0.1 \%), \\
\text { MS ( } n=1 ;<0.1 \%), \text { myelitis } \\
\text { transverse }(n=1 ;<0.1 \%)\end{array}$ \\
\hline
\end{tabular}


Table 5 continued

\begin{tabular}{|c|c|c|c|c|}
\hline Vaccine & Description & Administration & Efficacy (primary endpoint) & Safety \\
\hline $\begin{array}{c}\text { NVX-CoV2373 } \\
\text { (Novavax) }\end{array}$ & $\begin{array}{l}\text { Subunit recombinant SARS-CoV- } \\
2 \text { nanoparticle vaccine, } \\
\text { constructed from the full- } \\
\text { length wild-type SARS-CoV-2 } \\
\text { spike protein altered by } 2 \\
\text { proline substitutions; in Matrix } \\
\mathrm{M} \text { adjuvant }[50,51]\end{array}$ & $\begin{array}{l}\text { 5-50 } \mu \mathrm{g} \text { doses; } 1 \text { or } \\
2 \text { doses } \\
\text { (administered } \\
21 \text { days apart) in } \\
\text { clinical trial [51] }\end{array}$ & $\begin{array}{l}\text { No efficacy data available } \\
\text { At day } 35 \text { after first vaccination, } \\
\text { two } 5 \text { - } \mu \text { g doses }(n=29) \text { induced } \\
\text { geometric mean anti-spike IgG } \\
\text { ELISA levels and higher } \\
\text { neutralization responses than } \\
\text { those in convalescent serum from } \\
\text { COVID-19 patients (mostly } \\
\text { symptomatic) } \\
\text { Adjuvanted regimens induced } \\
\text { CD4 }{ }^{+} \text {T cell responses [51] }\end{array}$ & $\begin{array}{l}\text { AEs }\left(n=83^{\mathrm{k}}\right) \text { occurring after } \\
\text { dose } 2 \text { included [51] } \\
\text { Local: pain (grade 2, 7.7-12.5\%), } \\
\text { erythema or redness (grade 2, } \\
\text { 3.8-33.3\%), induration or } \\
\text { swelling (grade 2, 3.8\%), } \\
\text { tenderness (grade 2, 23.1-33.3\%; } \\
\text { grade 3, 4.2\%) } \\
\text { Systemic: joint pain/arthralgia } \\
\text { (grade 2, 3.8-4.8\%; grade 3, } \\
3.8-8.3 \% \text { ), fatigue (grade 2, } \\
\text { 4.8-19.2\%; grade 3, 3.8-8.3\%), } \\
\text { malaise (grade 2, 4.8-16.7\%; } \\
\text { grade 3, 8.3\%), headache } \\
\text { (grade 2, 4.8-16.7\%; grade 3, } \\
4.0 \% \text { ), muscle pain/myalgia } \\
\text { (grade 2, 8.3-11.5\%; grade 3, } \\
\text { 3.8-8.3\%), nausea or vomiting } \\
\text { (grade 3, 4.0\%) }\end{array}$ \\
\hline
\end{tabular}

Additional vaccine candidates are in various stages of clinical development and details can be found on the World Health Organization website [159] $A E$ adverse event, $E L I S A$, enzyme-linked immunosorbent assay, $L N P$ lipid nanoparticle, $m R N A$ messenger RNA, $P C R$, polymerase chain reaction, $v p$ virus particles

${ }^{\text {a }}$ Participants who received BNT162b2 or placebo as randomly assigned had no evidence of infection within 7 days after second dose and no major protocol deviations

${ }^{b}$ Reactogenicity subset; includes recipients of either BNT162b2 or placebo

c Includes participants who received $\geq 1$ dose of BNT162b2, irrespective of follow-up or follow-up time

${ }^{\mathrm{d}}$ Per-protocol population

e Solicited safety set

${ }^{\mathrm{f}}$ Incidences of 20.2/100,000 person-years over 5 years to cumulative incidence of 53.3/100,000 per year in the general population [173, 174]

${ }^{g}$ Per-protocol at risk set (excludes participants who had a positive PCR test between day 1 and day 14)

${ }^{\text {h }}$ Safety subset

${ }^{i}$ Primary efficacy population

${ }^{j}$ Participants who received $\geq 1$ dose of vaccine

k Participants who received 1 or 2 doses of NVX-CoV2373 with or without adjuvant

patients with MS treated with ocrelizumab also experienced decreases in IgG and IgM antibodies below the lower limit of normal 96-120 weeks after starting treatment with ocrelizumab, which is predictable on the basis of the mechanism of action of this therapy [123]. A single case report of loss of vaccinal immunity against varicella zoster virus suggests that ocrelizumab may impair varicella vaccines; however, this finding needs to be replicated in a larger cohort [150].

Interest in off-label treatment with rituximab for MS has increased [153, 154], but vaccination studies in patients with MS have not occurred to date. However, registry data $(N=822)$ show that $3 \%$ of patients with MS experience reductions in IgG below the lower limit of normal at some point during treatment [155]. Two systematic review and meta-analysis studies found 
a reduced response to pneumococcal vaccination [156, 157] and influenza vaccine [157] in patients with rheumatoid arthritis treated with rituximab but not for those who received antitumor necrosis factor alpha (TNF $\alpha)$ agent. Similarly, in a systematic review of studies in patients with rheumatoid arthritis or other inflammatory rheumatic diseases, rituximab also significantly decreased responses to an influenza vaccine, with tenfold lower hemagglutination inhibition assay titers observed in those administered rituximab less than 12 weeks before vaccination versus those administered rituximab more than 24 weeks before vaccination [158]. A second dose of the vaccine was needed to achieve responses comparable to those achieved with a single dose in healthy controls. No studies on vaccines are available for ofatumumab.

Data on alemtuzumab suggest vaccination should occur at least 6 months before starting treatment because depletion of $\mathrm{T}$ and $\mathrm{B}$ cells, as occurs with alemtuzumab treatment, would diminish response to vaccination [151].

The one study that included the DNA disrupter mitoxantrone reported an almost complete lack of response to influenza vaccination [90]. No studies on vaccines are available for cladribine.

\section{COVID-19 VACCINE TRIALS AND CONSIDERATIONS FOR PEOPLE WITH MS}

Multiple COVID-19 vaccines are in development [159] and a number are already being administered worldwide. Many target the spike protein of SARS-CoV-2, a protein expressed on the surface of the virus that facilitates entry into host cells, with the goal of generating robust humoral and $T$ cell responses [160, 161]. This protein binds to a receptor on the host cell surface and then causes the virus and host cell membranes to fuse $[53,162]$.

Three vaccines, BNT162b2 (developed by Pfizer and BioNTech), mRNA-1273 (developed by Moderna), and Ad26.COV2.S (VAC31518; JNJ-78436735; developed by Janssen Biotech), have received emergency use authorization but have not yet received approval from the US Food and Drug Administration at the time of this publication [163-165]. BNT162b2, mRNA1273, and another vaccine, ChAdOx1 nCoV-19 (AZD12222; developed by AstraZeneca and Oxford Vaccine Group), have received conditional marketing authorization in the European Union [166, 167]. BNT162b2 and mRNA-1273 contain lipid nanoparticle-formulated nucleoside-modified mRNA that encodes the SARSCoV-2 full-length spike protein but modified by two proline mutations [53, 168], and are administered in two doses [169]. Ad26.COV2.S (VAC31518; JNJ-78436735), administered in a single dose, and ChAdOx1 nCoV-19, administered in two doses, are recombinant replicationdeficient adenovirus vector vaccines encoding the spike protein gene [57-59].

Efficacy and safety data for these vaccines are shown in Table 5. Adverse events reported for all the vaccines included local reactions, such as pain at the site of administration, and systemic reactions that included headache, fever, and fatigue. Bell's palsy $(n=3)$ was reported with mRNA-1273 and facial paralysis $(n=2)$, brachial radiculitis $(n=1)$, Guillain-Barré syndrome $(n=1)$, transverse sinus thrombosis $(n=1)$; postvaccination syndrome $(n=1)$ was reported with Ad26.COV2.S (VAC31518; JNJ-78436735) $[59,170]$. Another candidate of interest is NVXCoV2373 (developed by Novavax), a subunit recombinant nanoparticle created from the spike protein $[50,51]$. No efficacy data are available yet; however, a small study showed inducement of anti-spike antibody and T cell responses [51] (Table 5).

Members of the MS community have expressed an interest in COVID-19 vaccination. A US online survey of people with MS in the spring of 2020, before any COVID-19 vaccines were available, found that approximately twothirds of respondents were willing or moderately willing to be vaccinated [175]. However, analyses focusing specifically on MS subgroups have yet to occur, and it is unknown how many people with MS have participated in COVID-19 vaccine studies. Thus, current knowledge pertaining to COVID-19 vaccination in patients with MS is based on conventional vaccines and anecdotal experience in those who have 
received the vaccine thus far. The percentage of seroconversion that is deemed sufficient for "protection" varies on the basis of what the vaccine/pathogen is, and people receiving certain DMTs may be able to mount some, albeit diminished, antibody response to vaccination. Duration of disease may also affect response to vaccination. Longer disease duration $(p=0.040$; odds ratio $=0.910$ ) has been associated with an insufficient response to influenza vaccine in people with MS treated with interferons, glatiramer acetate, natalizumab, fingolimod, and other DMTs [87]. These findings may be impacted not only by DMT but also by age, comorbidities, and other factors.

When thinking about the potential impact of MS DMTs on vaccine efficacy, the role of specific immune cell populations may be considered. For example, T cell signatures may be a more sensitive measure of past SARS-CoV-2 infection than antibody assays, as individuals with symptomatic infections or who required hospitalization had higher $\mathrm{T}$ cell responses [176]. This suggests that disease-specific memory $\mathrm{T}$ cells, in addition to antibody titers, may be measurable and reliable correlates of protection [176]. However, SARS-CoV-2-reactive CD $4^{+}$ $\mathrm{T}$ cells have been reported in $35-60 \%$ of unexposed individuals, suggesting possible cross-reactive $T$ cell recognition between other coronaviruses (e.g., common cold viruses) and COVID-19 [177-179]; the protective effect of such cross-reactive $\mathrm{T}$ cells is unclear.

Coronavirus-specific T cells from Middle Eastern respiratory syndrome (MERS) and severe acute respiratory syndrome (SARS) have been shown to have long-term persistence and contribute to protection [176, 180, 181]. Hence, DMTs that deplete or significantly impact T cells may affect the efficacy of potential COVID-19 vaccines. Moreover, the National Multiple Sclerosis Society advises waiting at least 12 weeks after the last dose of B cell-depleting treatment before vaccinating [80], as anti-CD20 antibodies (i.e., ocrelizumab) have been found to induce rapid and prolonged (up to 24 weeks) B cell depletion and attenuated humoral immune responsiveness to vaccination in people with MS [149]. Many clinicians advise their patients that if given a choice, they should receive a vaccine when available and worry about timing later. More data are needed to fully understand the necessity of the memory B cell population, an important target of antiCD20 therapies, to drive persistent antibody responses for extended periods of time following vaccination. Delaying therapy to allow for a more robust $B$ cell response to the COVID vaccine, only to potentially diminish this response when therapy is resumed, may be counterproductive. Lastly, the impact that B cell-depleting therapies may have on other components of the immune system, including $\mathrm{T}$ cells, may also need to be a consideration for vaccine administration.

Because of their persistence (as opposed to declining levels of antibodies), T cells may be the more important measure for determining the efficacy of COVID-19 vaccines. However, antibodies still clearly have a role in preventing future infection through neutralization of a virus before it can infect a cell. Indeed, vaccines are traditionally designed to elicit a very robust humoral immune response, in addition to a cellular immune response, to convey both protection from infection and prevention of disease. The COVID-19 vaccines are not an exception to this. Moreover, even if antibody titers decline, this does not negate the fact that memory B cells should still be present and able to contribute significantly to the prevention of future infection, highlighting the importance of maintaining adequate levels of both B cells and $\mathrm{T}$ cells during the vaccination period and beyond [45].

Although the evidence clearly demonstrates the importance of measuring and generating a $\mathrm{T}$ cell or cell-mediated response to COVID-19 vaccines (as evidenced by the detection of SARSCoV-2-specific $\mathrm{T}$ cells in convalescent patients [182]), it is important to remember that the immune response is a coordinated effort that must be orchestrated by both T cells and B cells (or cell-mediated and humoral immunity), as evidenced by the essential role that B cells have been shown to play in the generation of $\mathrm{T}$ cell memory $[39,183]$. 


\section{SUMMARY/CONCLUSION}

Infections can be associated with an increased risk of relapses or pseudo-relapses in people with MS. For this reason, vaccination is an important tool that should be utilized, whenever possible, to limit infection in this population. However, the use of DMTs, which alter various components of the immune response, may also reduce the vaccine immune response in people with MS. In light of the current COVID-19 global pandemic and the recent authorization of novel vaccines against COVID19, a better understanding of how MS DMTs may alter the immune response to vaccination is greatly needed. This review highlights previous studies of vaccine response in people with MS and focuses on how immunological impairment driven by various DMTs may impact successful vaccination strategies against COVID-19 in this patient population.

Immunological studies have shown that the coordinated interactions between $\mathrm{T}$ and $\mathrm{B}$ lymphocytes of the adaptive immune system are integral to the successful generation of immunological memory and production of neutralizing antibodies, following recognition of vaccine antigens by innate immune cells. $\mathrm{CD} 4^{+} \mathrm{T}$ cells play an essential role in facilitating both $\mathrm{CD}^{+} \mathrm{T}$ cell and $\mathrm{B}$ cell activation, but the inverse is also true, with B cells playing an important role in driving and sustaining $\mathrm{T}$ cell memory.

Previous studies of the immune response to vaccines other than COVID-19 in people with MS receiving various DMTs (Table 2) have shed some light on the key question of how each DMT or class of DMTs might affect the efficacy of a COVID-19 vaccine. Indeed, the data suggest that type 1 interferons, glatiramer acetate, and possibly teriflunomide may not significantly impair the response to vaccination, as opposed to those DMTs that rely on sequestration or depletion of large populations of immune cells, including S1P receptor modulators, alemtuzumab, cladribine, and anti-CD20 therapies. Other factors that could impact vaccine efficacy, including age and comorbidities, are beyond the scope of this review but should be considered. Benefits of vaccination, as outlined in guidance and guidelines from national and international MS groups, should be considered-even if vaccine efficacy may be compromised-when disease burden is high.

\section{ACKNOWLEDGEMENTS}

Funding. Biogen provided funding for this review and the journal's Rapid Service and Open Access Fees.

Medical Writing and Editorial Assistance. Meryl Mandle from Excel Medical Affairs wrote the first draft of the manuscript based on input from the authors, and Nathaniel Hoover and Jackie Parker from Excel Medical Affairs copyedited and styled the manuscript per journal requirements. Biogen provided funding for the medical writing support.

Authorship. All named authors meet the International Committee of Medical Journal Editors (ICMJE) criteria for authorship for this article, take responsibility for the integrity of the work as a whole, and have given their approval for this version to be published.

Authors' Contributions. Anne Gocke and Megan Vignos were involved with the conception and design of the work. Megan Vignos was involved in searches of the literature. Patricia K. Coyle, Anne Gocke, Megan Vignos, and Scott D. Newsome interpreted data for the work, reviewed and revised the work critically for important intellectual content, and provided final approval of the version to be published.

Disclosures. Patricia K. Coyle receives consulting and nonbranded speaker fees from Accordant, Biogen, Bristol-Myers Squibb, Celgene, Genzyme/Sanofi, GlaxoSmithKline, Janssen, Novartis, and Viela Bio; receives research support from Actelion, Alkermes, Celgene, Corrona, Genentech/Roche, MedDay, NINDS, and Novartis. Anne Gocke and Megan Vignos are employees of and own stock/stock options in Biogen. Scott D. Newsome has received 
consultant fees for scientific advisory boards from Biogen, Genentech, Bristol-Myers Squibb, EMD Serono, Novartis, Greenwich Biosciences; is an advisor for Autobahn Therapeutics and BioIncept; is a clinical adjudication committee member for a MedDay Pharmaceuticals clinical trial; and has received research funding (paid directly to institution) from Biogen, Novartis, Genentech, National MS Society, Department of Defense, and Patient Centered Outcomes Institute.

Compliance with Ethics Guidelines. This article is based on previously conducted studies and does not contain any new studies with human participants or animals performed by any of the authors.

Open Access. This article is licensed under a Creative Commons Attribution-NonCommercial 4.0 International License, which permits any non-commercial use, sharing, adaptation, distribution and reproduction in any medium or format, as long as you give appropriate credit to the original author(s) and the source, provide a link to the Creative Commons licence, and indicate if changes were made. The images or other third party material in this article are included in the article's Creative Commons licence, unless indicated otherwise in a credit line to the material. If material is not included in the article's Creative Commons licence and your intended use is not permitted by statutory regulation or exceeds the permitted use, you will need to obtain permission directly from the copyright holder. To view a copy of this licence, visit http://creativecommons.org/licenses/by$\mathrm{nc} / 4.0 /$.

\section{REFERENCES}

1. Compston A, Coles A. Multiple sclerosis. Lancet. 2008;372(9648):1502-17.

2. Javalkar V, McGee J, Minagar A. Chapter 1-clinical manifestations of multiple sclerosis: an overview. In: Minagar A, editor. Multiple sclerosis: a mechanistic view. Academic; 2016. p. 1-12.
3. Walton C, King R, Rechtman L, et al. Rising prevalence of multiple sclerosis worldwide: insights from the Atlas of MS, third edition. Mult Scler. 2020;26(14):1816-21.

4. MS International Federation. Atlas of MS. 2020. https://www.atlasofms.org/map/united-states-ofamerica/epidemiology/number-of-people-with-ms. Accessed Nov 13, 2020.

5. Thompson AJ, Baranzini SE, Geurts J, Hemmer B, Ciccarelli O. Multiple sclerosis. Lancet. 2018;391(10130):1622-36.

6. Castelo-Branco A, Chiesa F, Conte S, et al. Infections in patients with multiple sclerosis: a national cohort study in Sweden. Mult Scler Relat Disord. 2020;45:102420.

7. Persson R, Lee S, Ulcickas Yood $\mathrm{M}$, et al. Infections in patients diagnosed with multiple sclerosis: a multi-database study. Mult Scler Relat Disord. 2020;41:101982.

8. Nelson RE, Xie Y, DuVall SL, et al. Multiple sclerosis and risk of infection-related hospitalization and death in US veterans. Int J MS Care. 2015;17(5): 221-30.

9. Epstein DJ, Dunn J, Deresinski S. Infectious complications of multiple sclerosis therapies: implications for screening, prophylaxis, and management. Open Forum Infect Dis. 2018;5(8):ofy174.

10. Vollmer T. The natural history of relapses in multiple sclerosis. J Neurol Sci. 2007;256(Suppl 1):S513.

11. Steelman AJ. Infection as an environmental trigger of multiple sclerosis disease exacerbation. Front Immunol. 2015;6:520.

12. Oikonen M, Laaksonen M, Aalto V, et al. Temporal relationship between environmental influenza $A$ and Epstein-Barr viral infections and high multiple sclerosis relapse occurrence. Mult Scler. 2011;17(6): 672-80.

13. Buljevac D, Flach HZ, Hop WC, et al. Prospective study on the relationship between infections and multiple sclerosis exacerbations. Brain. 2002;125(Pt 5):952-60.

14. National Multiple Sclerosis Society. COVID-19 vaccine guidance for people living with MS. 2021. https://www.nationalmssociety.org/coronaviruscovid-19-information/multiple-sclerosis-andcoronavirus/covid-19-vaccine-guidance. Accessed Feb 1, 2021.

15. National Multiple Sclerosis Society. Immunization. https://www.nationalmssociety.org/For- 
Professionals/Clinical-Care/Managing-MS/ Immunization. Accessed Nov 16, 2020.

16. Farez MF, Correale J, Armstrong MJ, et al. Practice guideline update summary: vaccine-preventable infections and immunization in multiple sclerosis: report of the Guideline Development, Dissemination, and Implementation Subcommittee of the American Academy of Neurology. Neurology. 2019;93(13):584-94.

17. Lebrun C, Vukusic S, French Group for Recommendations in Multiple Sclerosis (France4MS) and the Société Francophone de la Sclérose En Plaques (SFSEP). Immunization and multiple sclerosis: recommendations from the French Multiple Sclerosis Society. Mult Scler Relat Disord. 2019;31:173-88.

18. Riva A, Barcella V, Benatti SV, et al. Vaccinations in patients with multiple sclerosis: a Delphi consensus statement. Mult Scler. 2021;27(3):347-59.

19. MS International Federation. MS, the coronavirus and vaccines-updated global advice. 2021. https:// www.msif.org/news/2020/02/10/the-coronavirusand-ms-what-you-need-to-know/. Accessed Feb 1, 2021.

20. Multiple Sclerosis Association of America. Vaccination safety in MS. 2020. https://mymsaa.org/PDFs/ vaccine-safety.pdf. Accessed Jan 15, 2021.

21. Longbrake EE, Cross AH. Effect of multiple sclerosis disease-modifying therapies on B cells and humoral immunity. JAMA Neurol. 2016;73(2):219-25.

22. Longbrake EE, Ramsbottom MJ, Cantoni C, Ghezzi L, Cross AH, Piccio L. Dimethyl fumarate selectively reduces memory $\mathrm{T}$ cells in multiple sclerosis patients. Mult Scler. 2016;22(8):1061-70.

23. Sepúlveda M, Llufriu S, Martínez-Hernández E, et al. Incidence and impact of COVID-19 in MS: a survey from a Barcelona MS unit. Neurol Neuroimmunol Neuroinflamm. 2021;8(2):e954.

24. Zabalza A, Cárdenas-Robledo S, Tagliani P, et al. COVID-19 in multiple sclerosis patients: susceptibility, severity risk factors and serological response. Eur J Neurol. 2020. https://doi.org/10.1111/ene. 14690.

25. Evangelou N, Garjani A, dasNair R, et al. Self-diagnosed COVID-19 in people with multiple sclerosis: a community-based cohort of the UK MS Register. J Neurol Neurosurg Psychiatry. 2020;92(1):107-9.

26. World Health Organization. WHO coronavirus disease (COVID-19) dashboard. Situation by country, territory and area. https://covid19.who.int/ table?tableChartType=heat. Accessed Feb 24, 2021.
27. Möhn N, Konen FF, Pul R, et al. Experience in multiple sclerosis patients with COVID-19 and disease-modifying therapies: a review of 873 published cases. J Clin Med. 2020;9(12):4067.

28. Sormani MP, De Rossi N, Schiavetti I, et al. Diseasemodifying therapies and coronavirus disease 2019 severity in multiple sclerosis. Ann Neurol. 2021. https://doi.org/10.1002/ana.26028.

29. Johns Hopkins University of Medicine. Coronavirus resource center mortality analysis. https:// coronavirus.jhu.edu/data/mortality. Accessed Apr 13, 2021.

30. Simpson-Yap S, De Brouwer E, Kalincik T, et al. Associations of DMT therapies with COVID-19 severity in multiple sclerosis. medRxiv. 2021. https://doi.org/10.1101/2021.02.08.21251316.

31. Reder A, Centonze D, Naylor ML, et al. COVID-19 in patients with multiple sclerosis: associations with disease-modifying therapies. CNS Drugs. 2021;35: 317-30.

32. Salter A, Fox RJ, Newsome SD, et al. Outcomes and risk factors associated with SARS-CoV-2 infection in a North American Registry of patients with multiple sclerosis. JAMA Neurol. 2021. https://doi.org/10. 1001/jamaneurol.2021.0688.

33. Mateen FJ, Rezaei S, Alakel N, Gazdag B, Kumar AR, Vogel A. Impact of COVID-19 on US and Canadian neurologists' therapeutic approach to multiple sclerosis: a survey of knowledge, attitudes, and practices. J Neurol. 2020;267(12):3467-75.

34. Turvey SE, Broide DH. Innate immunity. J Allergy Clin Immunol. 2010;125(2 Suppl 2):S24-32.

35. Marshall JS, Warrington R, Watson W, Kim HL. An introduction to immunology and immunopathology. Allergy Asthma Clin Immunol. 2018;14(Suppl 2):49.

36. Coffman RL, Sher A, Seder RA. Vaccine adjuvants: putting innate immunity to work. Immunity. 2010;33(4):492-503.

37. Janeway CAJ, Travers P, Walport M, Shlomchik MJ. Immunobiology: the immune system in health and disease. 5th ed. New York: Garland Science; 2001.

38. Clem AS. Fundamentals of vaccine immunology. J Glob Infect Dis. 2011;3(1):73-8.

39. Petersone L, Edner NM, Ovcinnikovs V, et al. T cell/ B cell collaboration and autoimmunity: an intimate relationship. Front Immunol. 2018;9:1941. 
40. Siegrist C-A. Vaccine immunology. In: Plotkin SA, Orenstein WA, Offit PA, editors. Vaccines. 6th ed. Philadelphia: Saunders; 2013. p. 14-32.

41. Luckheeram RV, Zhou R, Verma AD, Xia B. CD4 ${ }^{+}$ T cells: differentiation and functions. Clin Dev Immunol. 2012;2012:925135.

42. Bonilla FA, Oettgen HC. Adaptive immunity. J Allergy Clin Immunol. 2010;125(2 Suppl 2):S33-40.

43. Tay RE, Richardson EK, Toh HC. Revisiting the role of $\mathrm{CD}^{+} \mathrm{T}$ cells in cancer immunotherapy-new insights into old paradigms. Cancer Gene Ther. 2021;28(1-2):5-17.

44. Lubbers R, van Essen MF, van Kooten C, Trouw LA. Production of complement components by cells of the immune system. Clin Exp Immunol. 2017;188(2):183-94.

45. Siegrist C-A, Lambert P-H. Chapter 2-how vaccines work. In: Bloom BR, Lambert P-H, editors. The vaccine book. San Diego: Academic; 2016. p. 33-42.

46. Whitmire JK, Asano MS, Kaech SM, et al. Requirement of B cells for generating CD4+ T cell memory. J Immunol. 2009;182(4):1868-76.

47. World Health Organization. WHO vaccine safety basics: learning manual. 2013. https://www.who. int/vaccine_safety/initiative/tech_support/Vaccinesafety-E-course-manual.pdf. Accessed Mar 3, 2021.

48. Pulendran B, Ahmed R. Immunological mechanisms of vaccination. Nat Immunol. 2011;12(6): 509-17.

49. Yadav DK, Yadav N, Khuran SMP. Chapter 26vaccines: present status and applications. In: Verma AS, Singh A, editors. Animal biotechnology. Oxford: Academic; 2014. p. 491-508.

50. Tian JH, Patel N, Haupt R, et al. SARS-CoV-2 spike glycoprotein vaccine candidate NVX-CoV2373 immunogenicity in baboons and protection in mice. Nat Commun. 2021;12(1):372.

51. Keech C, Albert G, Cho I, et al. Phase 1-2 trial of a SARS-CoV-2 recombinant spike protein nanoparticle vaccine. N Engl J Med. 2020;383(24):2320-32.

52. Geall AJ, Mandl CW, Ulmer JB. RNA: the new revolution in nucleic acid vaccines. Semin Immunol. 2013;25(2):152-9.

53. Corbett KS, Edwards DK, Leist SR, et al. SARS-CoV-2 mRNA vaccine design enabled by prototype pathogen preparedness. Nature. 2020;586(7830):567-71.
54. Pardi N, Hogan MJ, Porter FW, Weissman D. mRNA vaccines-a new era in vaccinology. Nat Rev Drug Discov. 2018;17(4):261-79.

55. Dudek T, Knipe DM. Replication-defective viruses as vaccines and vaccine vectors. Virology. 2006;344(1):230-9.

56. Gilbert SC. T-cell-inducing vaccines-what's the future. Immunology. 2012;135(1):19-26.

57. COVID-19 vaccine AstraZeneca suspension for injection. COVID-19 vaccine (ChAdOx1-S [recombinant]) [summary of product characteristics]. Södertälje: AstraZeneca AB; 2021.

58. Bos R, Rutten L, van der Lubbe JEM, et al. Ad26 vector-based COVID-19 vaccine encoding a prefusion-stabilized SARS-CoV-2 spike immunogen induces potent humoral and cellular immune responses. NPJ Vaccines. 2020;5:91.

59. Janssen Biotech (a pharmaceutical company of Johnson \& Johnson). COVID-19 vaccine Ad26. COV2.S VAC31518 (JNJ-78436735). Sponsor briefing document. Vaccines and related biological products advisory committee. 2021. https://www. fda.gov/media/146219/download. Accessed Feb 26, 2021.

60. Maki J, Guiot AL, Aubert M, et al. Oral vaccination of wildlife using a vaccinia-rabies-glycoprotein recombinant virus vaccine (RABORAL V-RG ${ }^{\circledR}$ ): a global review. Vet Res. 2017;48(1):57.

61. Zhang C, Maruggi G, Shan H, Li J. Advances in mRNA vaccines for infectious diseases. Front Immunol. 2019;10:594.

62. SHINGRIX (Zoster Vaccine Recombinant, Adjuvanted), suspension for intramuscular injection. Research Triangle Park: GlaxoSmithKline Biologicals; 2019.

63. Lobaina Mato Y. Nasal route for vaccine and drug delivery: features and current opportunities. Int J Pharm. 2019;572:118813.

64. Lemoine C, Thakur A, Krajišnik D, et al. Technological approaches for improving vaccination compliance and coverage. Vaccines (Basel). 2020;8(2): 304.

65. Li AV, Moon JJ, Abraham W, et al. Generation of effector memory T cell-based mucosal and systemic immunity with pulmonary nanoparticle vaccination. Sci Transl Med. 2013;5(204):204ra130.

66. Tangye SG, Ma CS, Brink R, Deenick EK. The good, the bad and the ugly-TFH cells in human health and disease. Nat Rev Immunol. 2013;13(6):412-26. 
67. Centers for Disease Control and Prevention. Immunization schedules. https://www.cdc.gov/ vaccines/schedules/hcp/imz/adult.html. Accessed Mar 9, 2021.

68. Ayling K, Vedhara K, Fairclough L. Measuring vaccine responses in the multiplex era. In: Yan $\mathrm{Q}$, editor. Psychoneuroimmunology: methods and protocols. 2nd ed. New York: Springer; 2018. p. 327-40.

69. Zacour M, Ward BJ, Brewer A, et al. Standardization of hemagglutination inhibition assay for influenza serology allows for high reproducibility between laboratories. Clin Vaccine Immunol. 2016;23(3): 236-42.

70. Zimmermann P, Curtis N. Factors that influence the immune response to vaccination. Clin Microbiol Rev. 2019;32(2):e00084-e118.

71. US Department of Health and Human Services, Food and Drug Administration, Center for Biologics Evaluation and Research. Guidance for industry: clinical data needed to support the licensure of pandemic influenza vaccines. 2007. https://www. fda.gov/regulatory-information/search-fdaguidance-documents/clinical-data-needed-supportlicensure-pandemic-influenza-vaccines. Accessed Mar 3, 2021.

72. Ong EZ, Chan YFZ, Leong WY, et al. A dynamic immune response shapes COVID-19 progression. Cell Host Microbe. 2020;27(6):879-82.e2.

73. Gil-Etayo FJ, Suàrez-Fernández $\mathrm{P}$, Cabrera-Marante $\mathrm{O}$, et al. T-helper cell subset response is a determining factor in COVID-19 progression. Front Cell Infect Microbiol. 2021;11:624483.

74. Pulendran B, Li S, Nakaya HI. Systems vaccinology. Immunity. 2010;33(4):516-29.

75. Yang WH, Dionne $\mathrm{M}$, Kyle $\mathrm{M}$, et al. Long-term immunogenicity of an ASO3-adjuvanted influenza A(H1N1)pdm09 vaccine in young and elderly adults: an observer-blind, randomized trial. Vaccine. 2013;31(40):4389-97.

76. Pereira B, Xu XN, Akbar AN. Targeting inflammation and immunosenescence to improve vaccine responses in the elderly. Front Immunol. 2020;11: 583019.

77. Kurupati R, Kossenkov A, Haut L, et al. Race-related differences in antibody responses to the inactivated influenza vaccine are linked to distinct pre-vaccination gene expression profiles in blood. Oncotarget. 2016;7(39):62898-911.

78. Löbermann M, Boršo D, Hilgendorf I, Fritzsche C, Zettl UK, Reisinger EC. Immunization in the adult immunocompromised host. Autoimmun Rev. $2012 ; 11(3): 212-8$.

79. American Academy of Neurology. Position statement on COVID19 vaccination. https://www.aan. com/policy-and-guidelines/policy/positionstatements/aan-position-statement-on-covid-19vaccination/. Accessed Feb 2, 2021.

80. National Multiple Sclerosis Society. Timing MS medications with COVID-19 mRNA vaccines. https://www.nationalmssociety.org/coronaviruscovid-19-information/multiple-sclerosis-andcoronavirus/covid-19-vaccine-guidance/TimingMS-Medications-with-COVID-19-mRNA-Vaccines. Accessed Apr 19, 2021.

81. Société Francophone de la Sclérose En Plaques. MS/ NMOSD recommendations and COVID19 vaccines [French]. 2020. https://sfsep.org/recommandationssep-nmosd-et-vaccins-anti-covid19/. Accessed Feb $2,2021$.

82. Association of British Neurologists. Guidance on vaccination for COVID-19 and neurological conditions. 2021. https://www.theabn.org/resource/ collection/65C334C7-30FA-45DB-93AA74B3A3A20293/ABN_Guidance_on_COVID-19_ Vaccinations_for_people_with_neurological_ conditions_9.1.21.pdf. Accessed Mar 1, 2021.

83. Moriabadi NF, Niewiesk S, Kruse N, et al. Influenza vaccination in MS: absence of T-cell response against white matter proteins. Neurology. 2001;56(7):938-43.

84. Nguyen J, Hardigan P, Kesselman MM, Demory BM. Immunogenicity of the influenza vaccine in multiple sclerosis patients: a systematic review and metaanalysis. Mult Scler Relat Disord. 2021;48:102698.

85. von Hehn C, Howard J, Liu S, et al. Immune response to vaccines is maintained in patients treated with dimethyl fumarate. Neurol Neuroimmunol Neuroinflamm. 2017;5(1):e409.

86. Bar-Or A, Freedman MS, Kremenchutzky M, et al. Teriflunomide effect on immune response to influenza vaccine in patients with multiple sclerosis. Neurology. 2013;81(6):552-8.

87. Metze C, Winkelmann A, Loebermann M, et al. Immunogenicity and predictors of response to a single dose trivalent seasonal influenza vaccine in multiple sclerosis patients receiving disease-modifying therapies. CNS Neurosci Ther. 2019;25(2): 245-54.

88. Mehling M, Fritz S, Hafner P, et al. Preserved antigen-specific immune response in patients with multiple sclerosis responding to IFN $\beta$-therapy. PLoS ONE. 2013;8(11):e78532. 
89. Schwid SR, Decker MD, Lopez-Bresnahan M, RebifInfluenza Vaccine Study Investigators. Immune response to influenza vaccine is maintained in patients with multiple sclerosis receiving interferon beta-1a. Neurology. 2005;65(12):1964-6.

90. Olberg HK, Cox RJ, Nostbakken JK, Aarseth JH, Vedeler CA, Myhr KM. Immunotherapies influence the influenza vaccination response in multiple sclerosis patients: an explorative study. Mult Scler. 2014;20(8):1074-80.

91. Hedegaard CJ, Krakauer M, Bendtzen K, Sørensen PS, Sellebjerg F, Nielsen CH. The effect of beta-interferon therapy on myelin basic protein-elicited CD4+ T cell proliferation and cytokine production in multiple sclerosis. Clin Immunol. 2008;129(1): 80-9.

92. Severa M, Farina C, Salvetti M, Coccia EM. Three decades of interferon- $\beta$ in multiple sclerosis: can we repurpose this information for the management of SARS-CoV2 infection? Front Immunol. 2020;11: 1459.

93. McNab F, Mayer-Barber K, Sher A, Wack A, O'Garra A. Type I interferons in infectious disease. Nat Rev Immunol. 2015;15(2):87-103.

94. Patterson JB, Thomis DC, Hans SL, Samuel CE. Mechanism of interferon action: double-stranded RNA-specific adenosine deaminase from human cells is inducible by alpha and gamma interferons. Virology. 1995;210(2):508-11.

95. Silverman RH. Viral encounters with $2^{\prime}, 5^{\prime}$-oligoadenylate synthetase and RNase L during the interferon antiviral response. J Virol. 2007;81(23): 12720-9.

96. Samuel CE. Adenosine deaminase acting on RNA (ADAR1), a suppressor of double-stranded RNAtriggered innate immune responses. J Biol Chem. 2019;294(5):1710-20.

97. Grebenciucova E, Pruitt A. Infections in patients receiving multiple sclerosis disease-modifying therapies. Curr Neurol Neurosci Rep. 2017;17(11):88.

98. BETASERON (interferon beta-1b) for injection, for subcutaneous use. Whippany: Bayer HealthCare Pharmaceuticals; 1993.

99. AVONEX (interferon beta-1a) injection, for intramuscular injection. Cambridge: Biogen; 2020.

100. EXTAVIA ${ }^{\circledR}$ (interferon beta-1b) for injection, for subcutaneous use. East Hanover: Novartis; 2020.

101. REBIF (interferon beta-1a), for subcutaneous injection. Rockland: EMD Serono; 2020.
102. PLEGRIDY (peginterferon beta-1a) injection, for subcutaneous injection. Cambridge: Biogen; 2020.

103. Graber JJ, McGraw CA, Kimbrough D, Dhib-Jalbut S. Overlapping and distinct mechanisms of action of multiple sclerosis therapies. Clin Neurol Neurosurg. 2010;112(7):583-91.

104. Korporal M, Haas J, Balint B, et al. Interferon betainduced restoration of regulatory T-cell function in multiple sclerosis is prompted by an increase in newly generated naive regulatory $\mathrm{T}$ cells. Arch Neurol. 2008;65(11):1434-9.

105. COPAXONE (glatiramer acetate injection), for subcutaneous use. Parsippany: Teva Neuroscience; 2020.

106. Prod'homme T, Zamvil SS. The evolving mechanisms of action of glatiramer acetate. Cold Spring Harb Perspect Med. 2019;9(2):a029249.

107. Melnikov M, Sharanova S, Sviridova A, et al. The influence of glatiramer acetate on Th17-immune response in multiple sclerosis. PLoS ONE. 2020;15(10):e0240305.

108. AUBAGIO (teriflunomide) tablets, for oral use. Cambridge: Genzyme; 2020.

109. Bar-Or A, Pachner A, Menguy-Vacheron F, Kaplan J, Wiendl $\mathrm{H}$. Teriflunomide and its mechanism of action in multiple sclerosis. Drugs. 2014;74(6): 659-74.

110. GILENYA (fingolimod) capsules, for oral use. East Hanover: Novartis Pharmaceuticals; 2019.

111. Chun J, Hartung HP. Mechanism of action of oral fingolimod (FTY720) in multiple sclerosis. Clin Neuropharmacol. 2010;33(2):91-101.

112. Mandala S, Hajdu R, Bergstrom J, et al. Alteration of lymphocyte trafficking by sphingosine-1-phosphate receptor agonists. Science. 2002;296(5566):346-9.

113. Muls N, Dang HA, Sindic CJ, van Pesch V. Fingolimod increases CD39-expressing regulatory T cells in multiple sclerosis patients. PLOS ONE. 2014;9(11):e113025.

114. MAYZENT ${ }^{\circledR}$ (siponimod) tablets, for oral use. East Hanover: Novartis Pharmaceuticals; 2020.

115. ZEPOSIA ${ }^{\circledR}$ (ozanimod) capsules, for oral use. Summit: Celgene; 2020.

116. PONVORY ${ }^{\mathrm{TM}}$ (ponesimod) tablets, for oral use Titusville: Janssen Pharmaceuticals; 2021.

117. TECFIDERA ${ }^{\circledR}$ (dimethyl fumarate) delayed-release capsules, for oral use. Cambridge: Biogen; 2020. 
118. Fox RJ, Kita M, Cohan SL, et al. BG-12 (dimethyl fumarate): a review of mechanism of action, efficacy, and safety. Curr Med Res Opin. 2014;30(2): 251-62.

119. VUMERITY ${ }^{\circledR}$ (diroximel fumarate) delayed-release capsules, for oral use. Cambridge: Biogen; 2020.

120. BAFIERTAM ${ }^{\mathrm{TM}}$ (monomethyl fumarate) delayed-release capsules, for oral use. High Point: Banner Life Sciences; 2020.

121. TYSABRI (natalizumab) injection, for intravenous use. Cambridge: Biogen; 2015-2020.

122. Hutchinson M. Natalizumab: a new treatment for relapsing remitting multiple sclerosis. Ther Clin Risk Manag. 2007;3(2):259-68.

123. OCREVUS ${ }^{\circledR} \quad$ (ocrelizumab) injection, for intravenous use. South San Francisco: Genentech; 2020.

124. KESIMPTA ${ }^{\circledR}$ (ofatumumab) injection, for subcutaneous use. East Hanover: Novartis Pharmaceuticals; 2020.

125. RITUXAN ${ }^{\circledR}$ (rituximab) injection, for intravenous use. South San Francisco: Genentech; 2019.

126. LEMTRADA ${ }^{\circledR}$ (alemtuzumab) injection, for intravenous use. Cambridge: Genzyme; 2017.

127. Freedman MS, Kaplan JM, Markovic-Plese S. Insights into the mechanisms of the therapeutic efficacy of alemtuzumab in multiple sclerosis. J Clin Cell Immunol. 2013;4(4):1000152.

128. MAVENCLAD ${ }^{\circledR}$ (cladribine) tablets, for oral use. Rockland: EMD Serono; 2019.

129. NOVANTRONE ${ }^{\circledR}$ (mitoxantrone for injection concentrate). Rockland: EMD Serono; 2012.

130. Olberg HK, Eide GE, Cox RJ, et al. Antibody response to seasonal influenza vaccination in patients with multiple sclerosis receiving immunomodulatory therapy. Eur J Neurol. 2018;25(3):527-34.

131. Winkelmann A, Metze C, Frimmel S, Reisinger EC, Zettl UK, Loebermann M. Tick-borne encephalitis vaccination in multiple sclerosis: a prospective, multicenter study. Neurol Neuroimmunol Neuroinflamm. 2020;7(2):e664.

132. Proietti E, Bracci L, Puzelli S, et al. Type I IFN as a natural adjuvant for a protective immune response: lessons from the influenza vaccine model. J Immunol. 2002;169(1):375-83.

133. Day SL, Ramshaw IA, Ramsay AJ, Ranasinghe C. Differential effects of the type I interferons alpha4, beta, and epsilon on antiviral activity and vaccine efficacy. J Immunol. 2008;180(11):7158-66.

134. Bar-Or A, Wiendl H, Miller B, et al. Randomized study of teriflunomide effects on immune responses to neoantigen and recall antigens. Neurol Neuroimmunol Neuroinflamm. 2015;2(2):e70.

135. Mehling M, Hilbert $P$, Fritz S, et al. Antigen-specific adaptive immune responses in fingolimod-treated multiple sclerosis patients. Ann Neurol. 2011;69(2): 408-13.

136. Kappos L, Mehling M, Arroyo R, et al. Randomized trial of vaccination in fingolimod-treated patients with multiple sclerosis. Neurology. 2015;84(9): 872-9.

137. Mehling M, Eichin D, Hafner P, Hönger G, Kappos L, Hess C. Avidity of vaccine-induced influenza IgG fails to increase in fingolimod-treated patients with MS. Neurol Neuroimmunol Neuroinflamm. 2014;1(3):e28.

138. Signoriello E, Bonavita S, Sinisi L, et al. Is antibody titer useful to verify the immunization after VZV vaccine in MS patients treated with fingolimod? A case series. Mult Scler Relat Disord. 2020;40:101963.

139. Boulton C, Meiser K, David OJ, Schmouder R. Pharmacodynamic effects of steady-state fingolimod on antibody response in healthy volunteers: a 4-week, randomized, placebo-controlled, parallel-group, multiple-dose study. J Clin Pharmacol. 2012;52(12):1879-90.

140. Berger JR. Varicella vaccination after fingolimod: a case report. Mult Scler Relat Disord. 2013;2(4): 391-4.

141. Issa NP, Hentati A. VZV encephalitis that developed in an immunized patient during fingolimod therapy. Neurology. 2015;84(1):99-100.

142. Connor LM, Harvie MC, Rich FJ, et al. A key role for lung-resident memory lymphocytes in protective immune responses after BCG vaccination. Eur J Immunol. 2010;40(9):2482-92.

143. Ciabattini A, Pettini E, Fiorino F, Prota G, Pozzi G, Medaglini D. Distribution of primed T cells and antigen-loaded antigen presenting cells following intranasal immunization in mice. PLoS ONE. 2011;6(4):e19346.

144. Flórido M, Muflihah H, Lin LCW, et al. Pulmonary immunization with a recombinant influenza $A$ virus vaccine induces lung-resident $\mathrm{CD}^{+}$memory $T$ cells that are associated with protection against tuberculosis. Mucosal Immunol. 2018;11(6): 1743-52. 
145. Ufer M, Shakeri-Nejad K, Gardin A, et al. Impact of siponimod on vaccination response in a randomized, placebo-controlled study. Neurol Neuroimmunol Neuroinflamm. 2017;4(6):e398.

146. Sheffield JK, Janjua A, Campagnolo D, Raghupathi $\mathrm{K}$, Agafonova N, Cree BAC. Incidence and outcomes of varicella zoster virus (VZV) reactivation in the ozanimod phase-3 clinical program (SUNBEAM and RADIANCE) in relapsing multiple sclerosis (RMS). Eur J Neurol. 2018;25:528.

147. Kaufman M, Pardo G, Rossman H, Sweetser MT, Forrestal F, Duda P. Natalizumab treatment shows no clinically meaningful effects on immunization responses in patients with relapsing-remitting multiple sclerosis. J Neurol Sci. 2014;341(1-2):22-7.

148. Vågberg M, Kumlin U, Svenningsson A. Humoral immune response to influenza vaccine in natalizumab-treated MS patients. Neurol Res. 2012;34(7): 730-3.

149. Bar-Or A, Calkwood JC, Chognot C, et al. Effect of ocrelizumab on vaccine responses in patients with multiple sclerosis: the VELOCE study. Neurology. 2020;95(14):e1999-2008.

150. Rapisarda L, Valentino P, Barone S, et al. Varicella zoster immunity loss in multiple sclerosis patient treated with ocrelizumab. Clin Immunol. 2021;223: 108554 .

151. McCarthy CL, Tuohy O, Compston DA, Kumararatne DS, Coles AJ, Jones JL. Immune competence after alemtuzumab treatment of multiple sclerosis. Neurology. 2013;81(10):872-6.

152. Longbrake EE, Mao-Draayer $\mathrm{Y}$, Cascione M, et al. Dimethyl fumarate treatment shifts the immune environment toward an anti-inflammatory cell profile while maintaining protective humoral immunity. Mult Scler. 2020. https://doi.org/10. $1177 / 1352458520937282$.

153. Berntsson SG, Kristoffersson A, Boström I, Feresiadou A, Burman J, Landtblom AM. Rapidly increasing off-label use of rituximab in multiple sclerosis in Sweden-outlier or predecessor? Acta Neurol Scand. 2018;138(4):327-31.

154. Ineichen BV, Moridi T, Granberg T, Piehl F. Rituximab treatment for multiple sclerosis. Mult Scler. 2020;26(2):137-52.

155. Salzer J, Svenningsson R, Alping P, et al. Rituximab in multiple sclerosis: a retrospective observational study on safety and efficacy. Neurology. 2016;87(20):2074-81.

156. Hua C, Barnetche T, Combe B, Morel J. Effect of methotrexate, anti-tumor necrosis factor $\alpha$, and rituximab on the immune response to influenza and pneumococcal vaccines in patients with rheumatoid arthritis: a systematic review and metaanalysis. Arthritis Care Res (Hoboken). 2014;66(7): 1016-26.

157. van Aalst M, Langedijk AC, Spijker R, de Bree GJ, Grobusch MP, Goorhuis A. The effect of immunosuppressive agents on immunogenicity of pneumococcal vaccination: a systematic review and meta-analysis. Vaccine. 2018;36(39):5832-45.

158. Gabay C, Bel M, Combescure C, et al. Impact of synthetic and biologic disease-modifying antirheumatic drugs on antibody responses to the AS03-adjuvanted pandemic influenza vaccine: a prospective, open-label, parallel-cohort, single-center study. Arthritis Rheum. 2011;63(6):1486-96.

159. World Health Organization. Draft landscape and tracker of COVID-19 candidate vaccines. 2021. https://www.who.int/publications/m/item/draftlandscape-of-covid-19-candidate-vaccines. Accessed Mar 5, 2021.

160. Watanabe Y, Allen JD, Wrapp D, McLellan JS, Crispin M. Site-specific glycan analysis of the SARSCoV-2 spike. Science. 2020;369(6501):330-3.

161. Funk CD, Laferrière C, Ardakani A. A snapshot of the global race for vaccines targeting SARS-CoV-2 and the COVID-19 pandemic. Front Pharmacol. 2020;11:937.

162. Li F. Structure, function, and evolution of coronavirus spike proteins. Annu Rev Virol. 2016;3(1): 237-61.

163. US Food and Drug Administration. FDA takes key action in fight against COVID-19 by issuing emergency use authorization for first COVID-19 vaccine [press release]. 2020. https://www.fda.gov/newsevents/press-announcements/fda-takes-key-actionfight-against-covid-19-issuing-emergency-useauthorization-first-covid-19. Accessed Dec 16, 2020.

164. US Food and Drug Administration. FDA takes additional action in fight against COVID-19 by issuing emergency use authorization for second COVID-19 vaccine [press release]. 2020. https:// www.fda.gov/news-events/press-announcements/ fda-takes-additional-action-fight-against-covid-19issuing-emergency-use-authorization-second-covid. Accessed Dec 19, 2020.

165. US Food and Drug Administration. FDA issues emergency use authorization for third COVID-19 vaccine [press release]. 2021. https://www.fda.gov/ news-events/press-announcements/fda-issuesemergency-use-authorization-third-covid-19vaccine. Accessed Mar 3, 2021. 
166. AstraZeneca. COVID-19 Vaccine AstraZeneca authorised for use in the EU [press release]. 2021. https://www.astrazeneca.com/content/astraz/ media-centre/press-releases/2021/covid-19-vaccineauthorised-for-use-in-the-eu.html. Accessed Feb 1, 2021.

167. European Medicines Agency. COVID-19 vaccines: authorised. https://www.ema.europa.eu/en/ human-regulatory/overview/public-health-threats/ coronavirus-disease-covid-19/treatments-vaccines/ vaccines-covid-19/covid-19-vaccinesauthorised\#authorised-covid-19-vaccines-section. Accessed Mar 1, 2021.

168. Vogel AB, Kanevsky I, Che Y, et al. BNT162b vaccines are immunogenic and protect non-human primates against SARS-CoV-2. bioRxiv. 2020. https://doi.org/10.1101/2020.12.11.421008.

169. US Food and Drug Administration. FDA statement on following the authorized dosing schedules for COVID-19 vaccines [press release]. 2021. https:// www.fda.gov/news-events/press-announcements/ fda-statement-following-authorized-dosingschedules-covid-19-vaccines. Accessed Jan 14, 2021.

170. Baden LR, El Sahly HM, Essink B, et al. Efficacy and safety of the mRNA-1273 SARS-CoV-2 vaccine. N Engl J Med. 2021;384(5):403-16.

171. Polack FP, Thomas SJ, Kitchin N, et al. Safety and efficacy of the BNT162b2 mRNA Covid-19 vaccine. N Engl J Med. 2020;383(27):2603-15.

172. Voysey M, Clemens SAC, Madhi SA, et al. Safety and efficacy of the ChAdOx1 nCoV-19 vaccine (AZD1222) against SARS-CoV-2: an interim analysis of four randomised controlled trials in Brazil, South Africa, and the UK. Lancet. 2021;397(10269): 99-111.

173. Monini S, Lazzarino AI, Iacolucci C, Buffoni A, Barbara M. Epidemiology of Bell's palsy in an Italian Health District: incidence and case-control study. Acta Otorhinolaryngol Ital. 2010;30(4):198.

174. Rowlands S, Hooper R, Hughes R, Burney P. The epidemiology and treatment of Bell's palsy in the UK. Eur J Neurol. 2002;9(1):63-7.
175. Ehde DM, Roberts MK, Herring TE, Alschuler KN. Willingness to obtain COVID-19 vaccination in adults with multiple sclerosis in the United States. Mult Scler Relat Disord. 2021;49:102788.

176. Gittelman RM, Lavezzo E, Snyder TM, et al. Diagnosis and tracking of past SARS-CoV-2 infection in a large study of $\mathrm{Vo}^{\prime}$, Italy through $\mathrm{T}$-cell receptor sequencing. medRxiv. 2021. https://doi.org/10. 1101/2020.11.09.20228023.

177. Mateus J, Grifoni A, Tarke A, et al. Selective and cross-reactive SARS-CoV-2 T cell epitopes in unexposed humans. Science. 2020;370(6512):89-94.

178. Braun J, Loyal L, Frentsch M, et al. SARS-CoV-2-reactive $\mathrm{T}$ cells in healthy donors and patients with COVID-19. Nature. 2020;587(7833):270-4.

179. Grifoni A, Weiskopf D, Ramirez SI, et al. Targets of $\mathrm{T}$ cell responses to SARS-CoV-2 coronavirus in humans with COVID-19 disease and unexposed individuals. Cell. 2020;181(7):1489-501.e15.

180. Channappanavar R, Fett C, Zhao J, Meyerholz DK, Perlman S. Virus-specific memory CD8 T cells provide substantial protection from lethal severe acute respiratory syndrome coronavirus infection. J Virol. 2014;88(19):11034-44.

181. Zhao J, Alshukairi AN, Baharoon SA, et al. Recovery from the Middle East respiratory syndrome is associated with antibody and T-cell responses. Sci Immunol. 2017;2(14):eaan5393.

182. Ni L, Ye F, Cheng ML, et al. Detection of SARS-CoV2-specific humoral and cellular immunity in COVID-19 convalescent individuals. Immunity. 2020;52(6):971-7.e3.

183. Marino J, Gonzalez-Nolasco B, Wang X, Orent W, Benichou G. Contrasting effects of B cell depletion on $\mathrm{CD}^{+}$and $\mathrm{CD}^{+}$memory $\mathrm{T}$ cell responses generated after transplantation. Am J Transplant. 2020;20(9):2551-8. 